\title{
Modelling an alkenone-like proxy record in the NW African upwelling
}

\author{
X. Giraud \\ Research Center Ocean Margins, Universität Bremen, Postfach 330 440, 28334 Bremen, Germany
}

Received: 28 November 2005 - Published in Biogeosciences Discuss.: 27 January 2006

Revised: 16 May 2006 - Accepted: 30 May 2006 - Published: 21 June 2006

\begin{abstract}
A regional biogeochemical model is applied to the NW African coastal upwelling between $19^{\circ} \mathrm{N}$ and $27^{\circ} \mathrm{N}$ to investigate how a water temperature proxy, alkenones, are produced at the sea surface and recorded in the slope sediments. The biogeochemical model has two phytoplankton groups: an alkenone producer group, considered to be coccolithophores, and a group comprising other phytoplankton. The Regional Ocean Modelling System (ROMS) is used to simulate the ocean circulation and takes advantage of the Adaptive Grid Refinement in Fortran (AGRIF) package to set up an embedded griding system. In the simulations the alkenone temperature records in the sediments are between 1.1 and $2.3^{\circ} \mathrm{C}$ colder than the annual mean SSTs. Despite the seasonality of the coccolithophore production, this temperature difference is not mainly due to a seasonal bias, nor to the lateral advection of phytoplankton and phytodetritus seaward from the cold near-shore waters, but to the production depth of the coccolithophores. If coretop alkenone temperatures are effectively recording the annual mean SSTs, the amount of alkenone produced must vary among the coccolithophores in the water column and depend on physiological factors (e.g. growth rate, nutrient stress).
\end{abstract}

\section{Introduction}

A large number of paleoceanographic studies use the alkenone ratio in sediments to reconstruct past sea surface temperatures (SSTs) (e.g. Zhao et al., 2000; Sicre et al., 2000, 2001; Sachs and Anderson, 2003). This approach is based on the discovery that the relative content of long-chain $\left(\mathrm{C}_{37}\right)$ unsaturated ketones (alkenones) in certain Haptophyte algae, especially the coccolithophores Emiliania huxleyi and species of the genus Gephyrocapsa, depends on the growth

Correspondence to: X. Giraud

(xgiraud@palmod.uni-bremen.de) temperature of these algae (Marlowe, 1984; Brassell et al., 1986; Conte et al., 1998). Prahl et al. (1988) calibrated a linear relation between an unsaturation alkenone index $\left(\mathrm{U}_{37}^{K^{\prime}}\right)$ and the growth temperature of an E. huxleyi strain in culture experiments. It was then confirmed that this index could be used in the open ocean to reconstruct SSTs from coretop alkenone measurements (Müller et al., 1998).

In order to be used as a paleotemperature proxy, the $\mathrm{U}_{37}^{K^{\prime}}$ has to fulfil certain criteria. The stability of the $\mathrm{U}_{37}^{K^{\prime}}$ signal in the water and sedimentary diagenesis are still questions. Some studies argue for possible modification of the original temperature signal (Hoefs et al., 1998; Gong and Hollander, 1999; Rontani et al., 2005), whereas other studies conclude that there is no diagenetic effect on the temperature record (e.g. Grimalt et al., 2000; Harvey, 2000). The species considered to be the main alkenone producer and which was used for the $\mathrm{U}_{37}^{K^{\prime}}$ calibration, E. huxleyi, is widely distributed in the present-day world ocean. The calibration has also been confirmed for other alkenone-producer species that appeared before E. huxleyi (Conte et al., 1998). Finally, the global coretop calibration of Müller et al. (1998), as well as other regional studies (e.g. Prahl et al., 2005), have established that the alkenone index was best correlated with annual mean SSTs. Thus the alkenone index is widely used to reconstruct past annual mean SSTs.

Nevertheless, the relationship between $\mathrm{U}_{37}^{K^{\prime}}$ and annual mean SSTs may be biased by different factors, particularly by the conditions of generation, transport and burial of the alkenones. In certain regions the seasonality of alkenone producers causes a bias towards spring (Conte et al., 1992) or winter period (Herbert et al., 1998). The depth of maximum alkenone concentration is not necessarily located at the sea surface, but corresponds to the depth of maximum chlorophyll concentration, and varies from the surface to subsurface (Lee and Schneider, 2005). The lateral advection of particles or resuspension and transport of sediments over long distances by strong surface or bottom currents may also produce

Published by Copernicus GmbH on behalf of the European Geosciences Union. 


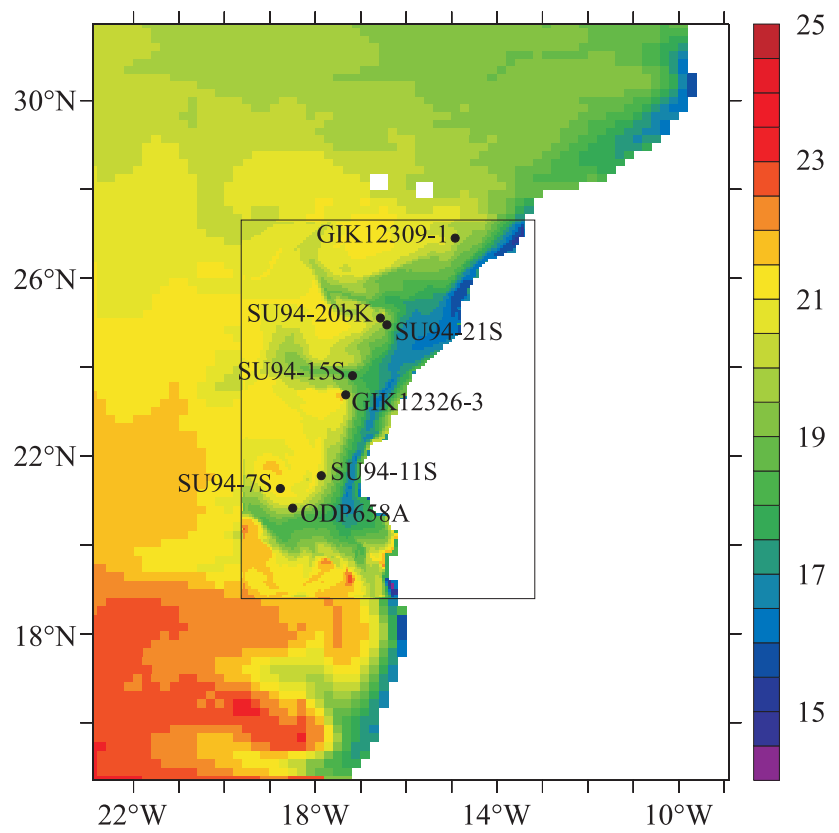

Fig. 1. Simulated SST $\left({ }^{\circ} \mathrm{C}\right)$ at 1 June over the area of the parent grid. The inner rectangle shows the area of the child grid. The locations of the sedimentary cores used in this study are also indicated.

mismatches between alkenone temperatures and SSTs (e.g. Benthien and Müller, 2000).

These considerations have lead to the notion of Integrated Production Temperature (IPT; Conte and Eglinton, 1993; Conte et al., 1998): the alkenone content of the sediments reflects the integrated production over years, thus including seasonal and the interannual variability. This may include changes in spatial origin to varying advection and mixing processes, and modification by differential losses in the water column or by diagenetic processes. The challenge in developing a good proxy is in getting an accurate picture of all processes affecting its production and settling. The IPT is the temperature recorded in sediments after the integration of all processes of production, transport and transformation and is therefore not necessarily the above annual mean SST. The notion of IPT can be extended to other temperature proxies, like the $\mathrm{Mg} / \mathrm{Ca}$ ratio in foraminiferal tests or statistical assemblages, since the planktonic tests may also experience advection/transport processes or a seasonal production bias.

A recent global calibration study (Conte et al., 2006) has shown a positive offset between surface water calibration and sediment calibration of the alkenone index, i.e. between coretop IPT and annual mean SSTs. Their results indicate that this deviation can be best explained if seasonality in production and/or thermocline production and diagenetic processes affect the sedimentary alkenone signal.

The modelling approach of the present study has the potential to investigate the relative impact of individual processes on the production and record of the alkenone sig- nal. Here we study the alkenone IPT in the context of the Northwest African coastal upwelling using a modelling approach, in order to compare the simulated IPT with SSTs and alkenone temperatures from coretop sediments and to evaluate potential biases.

A biogeochemical model has been developed to study the production and settling of the alkenone temperature proxy. It uses an alkenone-producer phytoplankton pool separated from the rest of the primary producers in order to capture the time and space distribution of alkenone production. It has been coupled to a regional ocean circulation model and applied to the Northwest African coastal upwelling along the Mauritanian coast between $19^{\circ} \mathrm{N}$ and $27^{\circ} \mathrm{N}$. The two models are presented in Sect. 2. Section 3 presents the results. In Sect. 4 , we discuss the influence of seasonality, production depth, lateral and vertical advection of phytoplankton and phytodetritus, and sediment resuspension, before concluding in Sect. 5.

\section{Model description and setup of simulations}

\subsection{Ocean model}

\subsubsection{Background}

The ocean circulation model is the Regional Ocean Modelling System (ROMS), which solves the primitive equations based on Boussinesq and hydrostatic approximations, and has a free surface, horizontal curvilinear coordinates, and a terrain-following (sigma coordinate) vertical curvilinear grid. A complete description can be found in Shchepetkin and McWilliams (2003, 2005). ROMS has been applied in various regional modelling studies, in particular coastal upwelling systems (Blanke et al., 2002; Marchesiello et al., 2003; Di Lorenzo et al., 2004).

We use a nesting approach in order to do high-resolution modelling on the Northwest African margin. A low resolution grid is set up on an extended domain between $15^{\circ} \mathrm{N}$ and $32^{\circ} \mathrm{N}$, the "parent" grid, and a higher-resolution embedded grid, or "child" grid, is centred within it on the study area, between $19^{\circ} \mathrm{N}$ and $28^{\circ} \mathrm{N}$ (Fig. 1). This embedded griding takes advantage of the AGRIF (Adaptive Grid Refinement in Fortran) package (Blayo and Debreu, 1999; Debreu, 2000; Debreu and Vouland, 2003). The scale factor between the parent and the child grids is set to 3 and applied to the time stepping as well. The result is that the parent and child grids have a resolution of $1 / 5^{\circ}$ and $1 / 15^{\circ}$, respectively, and baroclinic time steps of $1800 \mathrm{~s}$ and $600 \mathrm{~s}$, respectively. The number of barotropic time steps between baroclinic time steps is set to 45 . The grid has 20 levels in the vertical, with surface and bottom refinement using the stretching parameters $\theta_{s}=4.5$ and $\theta_{b}=0.9$ to allow for better representation of these boundary layers. 
The vertical mixing coefficients for momentum and tracers at the ocean interior are calculated according to the Large, McWilliams and Doney (Large et al., 1994) mixing scheme, and used in a nonlocal, K-Profile Parameterisation (KPP) scheme.

The topography is obtained by linear interpolation of the GEBCO Digital Atlas published by the British Oceanographic Data Centre (BODC) on behalf of IOC and IHO (IOC, IHO and BODC, 2003). Depths shallower than $10 \mathrm{~m}$ are reset to $10 \mathrm{~m}$. The topography is smoothed with a maximum slope parameter $(r=\operatorname{grad}(h) / h$, where $h$ is depth) of 0.2 .

\subsubsection{Forcing and initial conditions}

The model has been initialized using the temperature and salinity fields from Levitus and Boyer (1994) and Levitus et al. (1994) for the month of January, and from zero flow. A monthly climatology for the open boundaries has been produced using the World Ocean Atlas (Levitus and Boyer, 1994; Levitus et al., 1994) temperature and salinity fields and the Comprehensive Ocean-Atmosphere Data Set (COADS) (da Silva et al., 1994) winds, assuming a level of no motion at $2000 \mathrm{~m}$ to determine the total velocity. See also Marchesiello et al. (2003) and references therein for a description of the boundary conditions. The surface forcing is provided by mean seasonal heat and freshwater fluxes derived from the COADS. The wind forcing is from the daily reanalysis of the European Centre for Medium-range Weather Forcasts (ECMWF) dataset by Röske (2001) for the purpose of the Ocean Model Intercomparison Project (OMIP). The daily surface forcing is appropriate for short-term phases (pulsesrelaxation) of the coastal upwelling.

\subsection{Biogeochemical model}

The most abundant coccolithophore species, Emiliana huxleyi and Gephyrocapsa oceanica, are also though to be the main producers of alkenones in the present ocean (Volkman et al., 1995). Not all phytoplankton groups produce alkenones and coccolithophores do not necessarily represent a constant proportion of the total phytoplankton. Thus, a biogeochemical model of the alkenone temperature proxy should include an alkenone-producer phytoplankton group, representing the stated coccolithophores, and a non-alkenone-producer phytoplankton group, representing diatoms, flagellates, etc.

\subsubsection{Initial NPPZD model}

The biogeochemical model used for this study is derived from the NPZD model described in Oschlies and Garçon (1999) and Giraud et al. (2000, 2003). The total phytoplankton pool has been divided into two plankton functional types (PFTs). The two phytoplanktonic PFTs $\left(P_{1}\right.$ and $\left.P_{2}\right)$ have

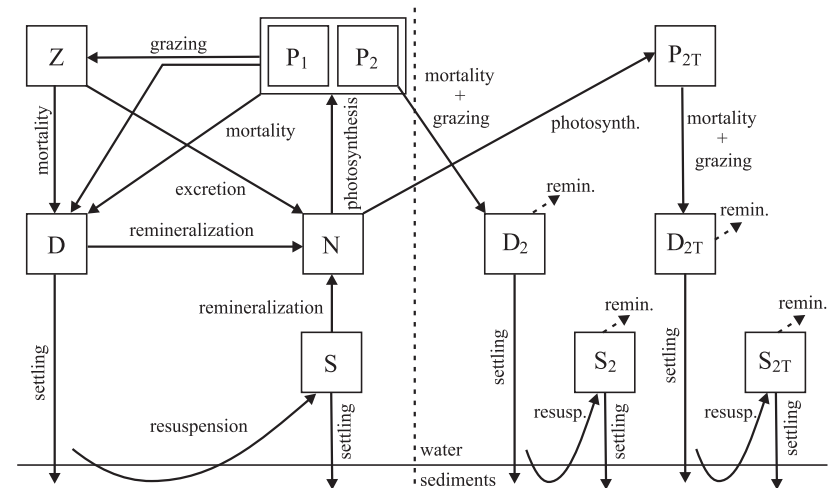

Fig. 2. Scheme of the biogeochemical model. The left half is the basic trophic chain model. The right half contains the added temperature-related state variables. The dashed arrows are nonconservative processes.

different growth rate parameters, which leads to different behaviours during the productive phase of the upwelling. One PFT has characteristics representative of diatoms $\left(P_{1}\right.$, hereafter referred to as diatoms), whereas the other has characteristics representative of coccolithophores $\left(P_{2}\right.$, hereafter referred to as coccolithophores).

The basic structure of this nitrogen-based ecosystem model (Fig. 2, left half) comprises five biological tracer components: nutrients $(N)$, diatoms $\left(P_{1}\right)$, coccolithophores $\left(P_{2}\right)$, zooplankton $(Z)$ and detritus $(D)$. These follow the sourceminus-sink differential equations:

$$
\begin{aligned}
& d P_{1} / d t= \\
& J_{1}(z, t, N) P_{1}-\frac{P_{1}}{P_{1}+P_{2}} G\left(P_{1}+P_{2}\right) Z-\mu_{P} P_{1}
\end{aligned}
$$

$d P_{2} / d t=$

$J_{2}(z, t, N) P_{2}-\frac{P_{2}}{P_{1}+P_{2}} G\left(P_{1}+P_{2}\right) Z-\mu_{P} P_{2}$

$d Z / d t=\gamma_{1} G\left(P_{1}+P_{2}\right) Z-\gamma_{2} Z-\mu_{Z} Z^{2}$

$d D / d t=$

$\left(1-\gamma_{1}\right) G\left(P_{1}+P_{2}\right) Z+\mu_{P}\left(P_{1}+P_{2}\right)+\mu_{Z} Z^{2}-\mu_{D} D$

$d N / d t=$

$\mu_{D} D+\gamma_{2} Z-J_{1}(z, t, N) P_{1}-J_{2}(z, t, N) P_{2}$

where $G$ is the zooplankton grazing function, and $J$ is the phytoplankton growth rate as a function of depth $z$, time $t$, and nutrients $N$. The five state variables $\left(N, P_{1}, P_{2}, Z, D\right)$ have units of mmol $\mathrm{N} \mathrm{m}^{-3}$. Model parameters and functions are given in Table 1. The grazing function $G$ is calculated with respect to total phytoplankton $\left(P_{1}+P_{2}\right)$ and applied to 
Table 1. Parameters of the biogeochemical model.

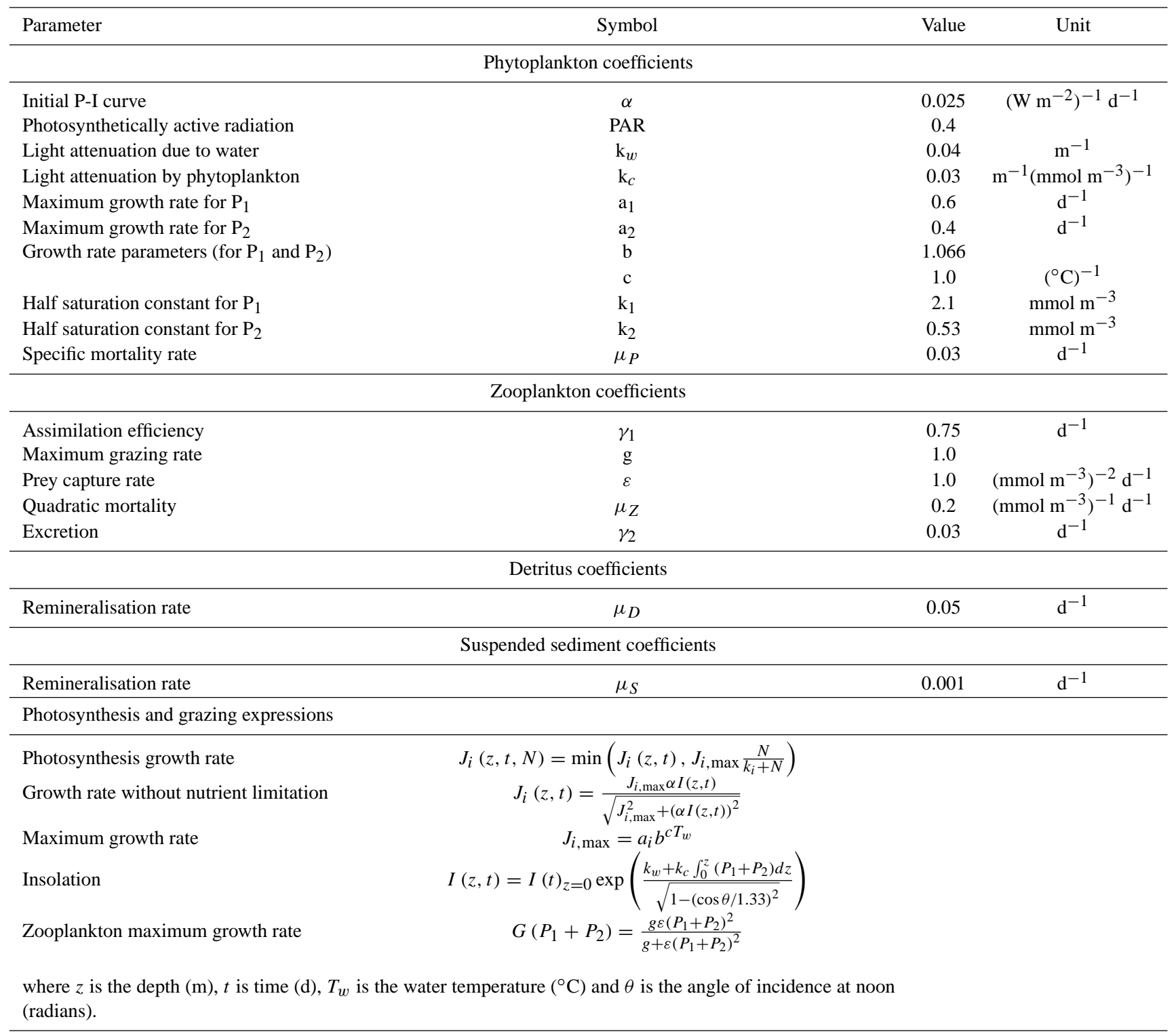

$P_{1}$ and $P_{2}$ proportionally. The shortwave radiation is provided by the COADS monthly climatology, with a $5^{\circ}$ resolution, and follows a reconstructed diurnal cycle.

An additional sinking term is applied to the detritus pool. In upwelling regions, fecal pellets and organic matter form aggregates having fast sinking velocities. Bory et al. (2001) report settling rates of $\sim 150 \mathrm{~m} \mathrm{~d}^{-1}$ at the oligotrophic site of the EUMELI program, off Cape Blanc, and suggest much faster settling rates at the mesotrophic site. Fischer et al. (1996) and Müller and Fischer (2001) also report sinking velocities for organic matter of the order of $280 \mathrm{~m} \mathrm{~d}^{-1}$ in the same mesotrophic context. Because we have only one detritus pool and since the study area covers eutrophic to olig- otrophic conditions, we used a constant sinking velocity of $200 \mathrm{~m} \mathrm{~d}^{-1}$ for the reference simulation.

The nitrate and phytoplankton fields were initialized from the World Ocean Atlas database (Conkright et al., 2002). The total phytoplankton biomass was calculated assuming a chlorophyll-a: $\mathrm{N}$ ratio of $1.59 \mathrm{mg}$ chla $(\mathrm{mmol} \mathrm{N})^{-1}$ (Oschlies and Garçon, 1999). The ratio between the initial coccolithophore and diatom concentrations is then set to 0.5 , the zooplankton concentration was set to $30 \%$ of the total phytoplankton, and there was no initial detritus or phytodetritus. 
Table 2. PFT growth parameters. The $k_{i}$ are half saturation constants for nitrate uptake $\left(\mathrm{mmol} \mathrm{m}^{-3}\right)$ and the $a_{i}$ are maximum growth rates $\left(d^{-1}\right)$.

\begin{tabular}{lcccc}
\hline \multirow{2}{*}{ References } & \multicolumn{2}{c}{ diatoms } & \multicolumn{2}{c}{ coccolithophores } \\
& $k_{1}$ & $a_{1}$ & $k_{2}$ & $a_{2}$ \\
\hline Eppley et al. (1969) & 1.9 & & $\leq 0.5$ & \\
Moore et al. (2002) & 2.5 & $3.0^{\mathrm{a}}$ & 0.5 & $3.0^{\mathrm{a}}$ \\
Chai et al. (2002) & & $3.0^{\mathrm{a}}$ & 0.5 & $2.0^{\mathrm{a}}$ \\
Gregg et al. (2003) & 1 & $2.0^{\mathrm{a}}$ & 0.5 & $1.5^{\mathrm{a}}$ \\
Le Quéré et al. (2005) & 1.2 & $0.6\left(2.1^{\mathrm{b}}\right)$ & 0.064 & $0.2\left(0.7^{\mathrm{b}}\right)$ \\
Buithenhuis (DGOM) & 2.1 & $0.6\left(2.1^{\mathrm{b}}\right)$ & 0.53 & $0.4\left(1.4^{\mathrm{b}}\right)$ \\
This study - reference simulation STD & 2.1 & $0.6\left(2.1^{\mathrm{b}}\right)$ & 0.53 & $0.4\left(1.4^{\mathrm{b}}\right)$ \\
\hline
\end{tabular}

a The parameter is scaled by the temperature function (see references).

b This value is calculated with the temperature function: $a_{i} 1.066^{T}$, with $T=20^{\circ} \mathrm{C}$.

${ }^{\mathrm{c}}$ DGOM: Dynamic Green Ocean Model. Available online at http://lgmacweb.env.uea.ac.uk/green_ocean/.

\subsubsection{Plankton functional types}

The parameterisation of the PFTs should be certainly based on observed or measured physiological features. These are unfortunately rare and the measured parameters (in situ or from laboratory experiments) are not always appropriate to fill the modellers' expectations. It also appears that the model structure does not allow a complete match with natural behaviours. The parameterisation of our model has therefore to reproduce the temporal and spatial coccolithophore distribution without having this full complexity of trophic relations. There are many factors discussed for causing coccolithophore blooms. In a study of the environmental control of living coccolithophores in the northern Arabian Sea, Andruleit et al. (2003) mention that the coccolithophore communities seemed to be more dependent on mixed layer depth and nutrient availability than on temperature and salinity changes. Critical irradiance and decreasing nitrate concentrations are also thought to be selective for upper ocean large scale coccolithophore blooms (Iglesias-Rodriguez et al., 2002). The possible factors to distinguish between coccolithophores and diatoms in the model are limited. The experience of former PFT models is therefore very valuable and constitutes a solid base for our purpose.

The phytoplankton growth rate function $J$ is applied similarly to both $P_{1}$ and $P_{2}$ but different maximum growth rates and half saturation constants for nitrate uptake are used for each PFT. These parameters determine the competitive ability of each PFT relative to the other. Table 2 gives a selection of these parameters from other PFT biogeochemical models or laboratory experiments. A maximum growth rate of $0.6 \mathrm{~d}^{-1}$ is widely used for phytoplankton in biogeochemistry models (Le Quéré et al., 2005), and is the value used for the initial NPZD model (Oschlies and Garçon, 1999; Giraud et al., 2000, 2003). The maximum growth rate for coccolithophores is usually lower than that of the diatoms, by about two thirds (Eppley et al., 1969; Chai et al., 2002; Gregg et al., 2003). The half saturation constant reflects the ability to use low levels of nutrients, and varies approximately in proportion to cell size and inversely with specific growth rate (Eppley et al., 1969). According to Eppley et al. (1969), the value of this parameter is $\leq 0.5 \mathrm{mmol} \mathrm{NO}_{3} \mathrm{~m}^{-3}$ for coccolithophores. Classical values for the half saturation constant of nitrate uptake are around $0.5 \mathrm{mmol} \mathrm{NO}_{3} \mathrm{~m}^{-3}$ for coccolithophores and range between 1 and $2.5 \mathrm{mmol} \mathrm{NO}_{3} \mathrm{~m}^{-3}$ for diatoms (Eppley et al., 1969; Chai et al., 2002; Moore et al., 2002, 2004; Gregg et al., 2003; Le Quéré, 2005). The parameter values used in this study are similar to those proposed by E. Buitenhuis in the Dynamic Green Ocean Project (available at http://lgmacweb.env.uea.ac.uk/green_ocean/). For diatoms and coccolithophores, the maximum growth rates were set to $0.6 \mathrm{~d}^{-1}$ and $0.4 \mathrm{~d}^{-1}$, respectively, and the half saturation constants to 2.1 and $0.53 \mathrm{mmol} \mathrm{NO}_{3} \mathrm{~m}^{-3}$, respectively (all listed for comparison on bottom line of Table 2).

\subsubsection{Modelling an alkenone temperature proxy}

The basic biogeochemical model provides for the development of the phytoplankton and the loop of the trophic chain. However, in order to track the alkenone temperature proxy from the surface to the bottom, the detritus pool produced by the coccolithophores has to be distinguished from the total detritus pool $(D)$. A new state variable is thus added: a phytodetritus pool $\left(D_{2}\right.$, in mmol $\left.\mathrm{N} \mathrm{m}^{-3}\right)$ having only the coccolithophores $\left(P_{2}\right)$ as a source (Fig. 2, right half). $D_{2}$ has most of the same characteristics as $D$ (remineralisation rate, mortality rate and sinking velocity) but the source-minus-sink differential equation for $D_{2}$ is:

$$
\begin{aligned}
& d D_{2} / d t= \\
& \left(1-\gamma_{1}\right) \frac{P_{2}}{P_{1}+P_{2}} G\left(P_{1}+P_{2}\right) Z+\mu_{P} P_{2}-\mu_{D} D_{2}
\end{aligned}
$$


Additional state variables are also needed to carry the information about the temperature at which the coccolithophores grew. However, considering only the advection of a temperature record would miss the information of the concentration of the coccolithophore or phytodetritus carrying this temperature record. For modelling purpose only, we thus introduce the concept of concentration-weighted temperature. The advection of the concentration-weighted temperature is a linear process both in regard of coccolithophore or phytodetritus concentrations and their temperature. At any time, the temperature record is retrieved by dividing the concentrationweighted temperature by the concentration. The idea is thus to run the described concentration state variables, $P_{2}$ and $D_{2}\left(\mathrm{mmol} \mathrm{N} \mathrm{m}{ }^{-3}\right)$, in parallel with two more state variables, $P_{2 T}$ and $D_{2 T}\left({ }^{\circ} \mathrm{C} \mathrm{mmol} \mathrm{N} \mathrm{m}^{-3}\right)$, giving concentrationweighted temperature. The alkenone temperatures of the coccolithophores, $T_{P 2}\left({ }^{\circ} \mathrm{C}\right)$, and of the phytodetritus, $T_{D 2}$ $\left({ }^{\circ} \mathrm{C}\right)$, are then simply:

$$
\begin{aligned}
& T_{P 2}=P_{2 T} / P_{2} \\
& T_{D 2}=D_{2 T} / D_{2}
\end{aligned}
$$

In other words, $T_{P 2}$ is the temperature in which the coccolithophorid pool grew and thus the alkenone temperature proxy. Similarly for $T_{D 2}$ but for the detritus pool, comprising dead coccolithophores and unassimilated zooplankton grazing material.

The exact role of the alkenones in the physiology of coccolithophores is not clear. It has been suggested that alkenones and associated compounds participate in the buoyancy of cells (Fernandez et al., 1994), somehow regulate membrane fluidity, or are associated with formation of coccoliths (Sawada and Shiraiwa, 2004). Some recent studies suggest that alkenones are metabolic storage lipids and that their metabolic utilisation is not a source of error in the temperature estimation (Epstein et al., 2001; Sawada and Shiraiwa, 2004). Whatever their exact physiological role, the important point here is their rate of turnover.

Conte et al. (1998) concluded that alkenone composition adapts rapidly to environmental conditions, even in stressed populations, and that alkenones turn over rapidly. We assume in our reference simulation that the alkenone ratio in the phytoplankton pool always reflects the surrounding water temperature ( $\left.T_{w}\right)$, so that at any time $T_{P 2}=T_{w}$.

However, it has also been suggested that newly-produced alkenones are added to an older stock (Epstein et al., 1998). One consequence of this would be a delay in the response of the phytoplankton pool to rapid changes in their environmental conditions. A modelling difficulty would then lie in the estimation of the rapidity of response. Following Epstein et al. (1998), we formulated an equation that accounts for the temperature of coccolithophores responding to local water temperature only during the growing phase, via incorporation of newly-produced alkenone into an older stock:

$$
d P_{2 T} / d t=
$$

$$
J_{2}(z, t, N) P_{2} T_{w}-\frac{P_{2}}{P_{1}+P_{2}} G\left(P_{1}+P_{2}\right) Z T_{P 2}-\mu_{P} P_{2} T_{P 2}
$$

This is tried in non-reference simulations and means that the $P_{2 T}$ pool grows proportionally to the coccolithophorid primary production $\left(J_{2} P_{2}\right)$ and to the local water temperature $\left(T_{w}\right)$. This pool is therefore a mixture of concentrationweighted temperatures from different times. However, the influence of earlier production is progressively removed by the processes of mortality and zooplankton grazing and transmitted to the phytodetritus pool $\left(D_{2 T}\right)$.

For the phytodetritus pool we assume that the temperature signal carried by alkenones is not modified by any diagenetic process. The variations of $D_{2 T}$ are then only due to mixing with other phytodetritus pools, remineralisation and coccolithophore mortality. The source-minus-sink equation for it, based on Eq. (6), is:

$$
\begin{aligned}
& d D_{2 T} / d t= \\
& \left(1-\gamma_{1}\right) \frac{P_{2}}{P_{1}+P_{2}} G\left(P_{1}+P_{2}\right) Z T_{P 2}+\mu_{P} P_{2} T_{P 2}-\mu_{D} D_{2} T_{D 2}
\end{aligned}
$$

\subsection{Sediment processes}

\subsubsection{Sediment transport}

The detritus pool carries the biogeochemical information from the surface to the sea floor but its final comparison with core sediments requires considering further transformation processes.

The detritus reaching the sea floor become sediment, which might be resuspended by bottom currents and transported in the water column. It may also form bottom boundary layer aggregates, acquiring different properties than the sinking detritus (Thomsen et al., 2002). In particular, the organic matter may stick to inorganic minerals, so that its remineralisation rate is lower.

Therefore we again added state variables to the biogeochemical model: suspended sediments $(S)$ and the associated temperature proxy pools, phytodetritic suspended sediments $\left(S_{2}\right)$ and its concentration-weighted temperature $\left(S_{2 T}\right)$. These originate only from $D, D_{2}$ and $D_{2 T}$, respectively (Fig. 2), via accumulating in the sea floor and being resuspended. Resuspension is by the bottom shear stress, with a flux $F_{S}\left(\mathrm{mmol} \mathrm{N} \mathrm{m}{ }^{-2} \mathrm{~d}^{-1}\right)$ given by:

$F_{S}=F_{B C}+F_{S T}$

where

$F_{B C}=K_{C} \frac{\tau_{b}-\tau_{C R}}{\tau_{C R}}$, for $\tau_{b}>\tau_{C R}$

and

$F_{S T}=K_{S}\left(H_{C R}-H\right)$, for $H<H_{C R}$

$F_{B C}$ is the resuspension flux associated with the bottom current shear stress, $K_{C}$ and $\mathrm{K}_{S}$ are erosion coefficients (mmol 
$\left.\mathrm{N} \mathrm{m}^{-2} \mathrm{~d}^{-1}\right), \tau_{b}$ is the bottom shear stress and $\tau_{C R}$ is the critical shear stress for resuspension (both in $\mathrm{N} \mathrm{m}^{-2}$ ). $F_{S T}$ is the resuspension flux associated with storm events and tides, $H$ is the water depth (m), and $H_{C R}$ is an empirical maximum depth of impact of this resuspension term.

The parameterisation of the resuspension processes is different for each study area (lakes, coastal domain, continental shelves), because of the many sediment types, grain sizes and cohesion properties. We attempt in this work to take into account the post-settling transport of sediments from the shelf and its influence on the continental slope accumulation, on the seasonal time scale. Fütterer (1983) interprets the grain size distribution on the shelf and slope off Northwest Africa as reflecting the action of currents and waves. The rework and erosion of the shelf sediments leaves only coarse material on the shelf and upper slope. The maximum organic matter content is located at around $1000 \mathrm{~m}$ to $2000 \mathrm{~m}$ depth on the slope off Cape Blanc. Our parameterisation is therefore set up to minimize the sedimentary accumulation of organic matter on the shelf.

The formulation of $F_{B C}$ is from a classical expression of the resuspension flux as a function of the bottom shear stress (Blom and Aalderink, 1998; Ribbe and Holloway, 2001). The critical shear stress $\tau_{C R}$ is set to $0.01 \mathrm{~N} \mathrm{~m}^{-2}$, corresponding to the limit of resuspension for organic material (Peterson, 1999).

The $F_{S T}$ term accounts for the impact of tidal currents and storm events, which are not explicitly modelled. The present formulation is empirical and the effects are limited to the continental shelf, with a maximum effect in shallow areas, but decreasing to zero at $200 \mathrm{~m}$ depth $\left(H_{C R}\right) . K_{S}$ is set to $5 \mathrm{mmol} \mathrm{m} \mathrm{m}^{-2} \mathrm{~d}^{-1}$, a value arrived at after a few sensitivity experiments with our model. A too-high value of this coefficient leads to non-negligible resuspension terms in deep water (continental slope or abyssal plain) and this seems unrealistic.

The total flux is limited to the amount available in the sediments so the whole process is conservative. Once in the water column, the $S$ components are advected by the ocean circulation model just like the other biogeochemical state variables. The only sink term (unless the resettling on the sea floor has the same sinking velocity as $D$ ) is the remineralisation:

$d S / d t=-\mu_{S} S$

This is also applied, with the same remineralisation rate and sinking velocity, to the $S_{2}$ and $S_{2 T}$ components (Fig. 2, Table 1). Only the remineralisation term applied to the $S$ component is goes back to the nutrient pool (Fig. 2).

\subsubsection{Sediment transformation over time}

The second sedimentary process is long-term transformation. Real sediments accumulate over centuries or millennia. This time scale is out of range of the simulations in this work, which reproduces only seasonal cycles over a few years at best. Since our simulations are for getting an average present-day picture, the realism of the sea surface and water column processes does not suffer because of this time scale limitation. Still, long-term diagenetic processes cannot be explicitly accounted for. However, alkenones are known to be among the most refractory lipids (Grimalt et al., 2000) and many studies suggest that the $\mathrm{U}_{37}^{K^{\prime}}$ index is not affected by diagenesis (e.g. Grimalt et al., 2000; Harvey, 2000). Therefore, the only expected effect of diagenesis is a reduction of the organic matter accumulation, without modification of the temperature-record.

\subsection{Simulations setup}

The biogeochemical model is applied on both parent and child grids, with a time step half of the baroclinic time step and with the parent grid providing the boundary conditions for the child grid. The biogeochemical fields exported from the child grid do not influence the parent. We believe this is not a major shortcoming since few feedbacks are to be expected once water flows out of the child grid. The current loops formed by eddies are on small scales compared to the extent of the study area and their eventual feedback would only impact the borders.

Each simulation includes two model years using only the ocean model on the parent grid, followed by one model year using both the ocean and biogeochemical models and the parent and child grids to achieve full development and coherent distribution of the biogeochemical tracers. This constitutes the spin-up phase. Marchesiello (2003) showed that the equilibrium of the ocean circulation is reached after 2-3 years in a similar configuration. Three additional model years are then run and averaged to provide the results presented hereafter. This averaging removes interannual variability. In the following figures and discussion of results only the child grid is considered.

Different simulations were performed. The reference simulation, "STD", assumes that the alkenone temperature of the coccolithophores is always equal to the surrounding water temperature, as described in Sect. 2.2.3. The simulation "DELAY" considers the inertia of the temperature record in coccolithophores (using Eq. 9), as discussed in Sect. 2.2.3.

For both simulations, a series of sensitivity tests were performed. The sensitivity test "GROWTH" considers a different parameterisation of growth rate and light affinity of the coccolithophore PFT in order to favour a production at shallower depth. In sensitivity test "NOADV", the lateral advection of detritus particles was disabled in order to evaluate its impact on the IPT. In sensitivity test "SINKING", the sinking rate of the detritus is not constant but set as a function of depth. The motivation and settings of these sensitivity tests are presented and commented in the discussion of Sect. 4.

The simulations were performed on a $3.6 \mathrm{GHz} \mathrm{PC}$ under a Scientific Linux CERN 3 system. For each simulation, the 

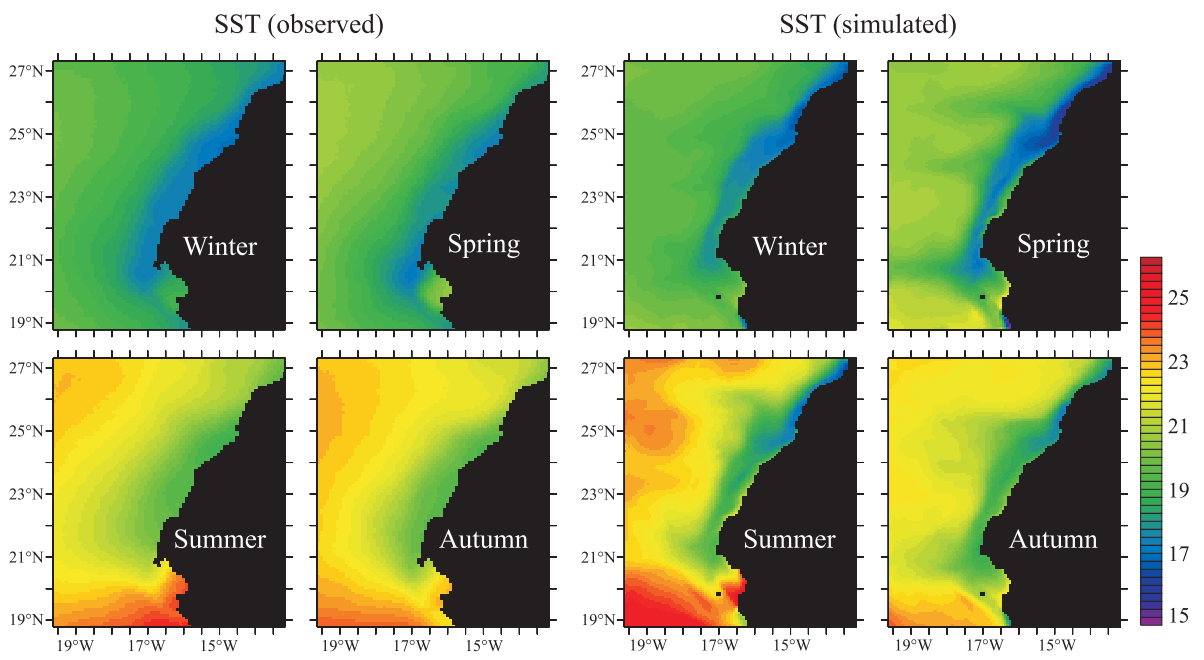

Fig. 3. Seasonal SSTs $\left({ }^{\circ} \mathrm{C}\right)$ from the AVHRR Pathfinder Global $9 \mathrm{~km}$ Pentad SST Climatology (left) (PODAAC, 2001) and from the model (right). (winter: January-March, spring: April-June, summer: July-September, autumn: October-December).

3-years spin-up phase takes 5 days computing and each additional simulated year takes another 5 days.

\section{Results}

\subsection{Hydrography}

The hydrographical results are identical for all simulations. The seasonal variations of sea-surface elevation, annual mean SST and surface kinetic energy are extremely similar from year to year, showing the stability of the model.

Figure 3 compares seasonal simulated SSTs with satellite observations (PODAAC, 2001; http://podaac.jp.nasa.gov). The upwelling that develops on the continental shelf brings deep cold water to the coast, where SSTs are thus lower than $17^{\circ} \mathrm{C}$. Offshore SSTs show a strong seasonal pattern, warming to $25^{\circ} \mathrm{C}$ in summer, while in winter, the onshoreoffshore temperature gradient is only $3-4^{\circ} \mathrm{C}$. The simulated SSTs show generally a higher onshore-offshore gradient than observations, with colder SSTs at the coast and warmer SSTs offshore. The discrepancy is within $\pm 3^{\circ} \mathrm{C}$. Nevertheless, on the continental slope where cores are located, the simulated SSTs are identical to observations.

North of Cape Blanc, the coastal surface current flows equatorwards all year long. South of Cape Blanc, the currents flow northward in summer and southward in winter. The coastal currents form eddies that contribute to the exchange between coastal and offshore waters. All these patterns are in good agreement with the observations of Mittelstaedt (1991).

The mixed layer depth (MLD) is also an important feature to look at, since it may drive the mixing of the phytoplankton and the influx of deep nutrient to the surface ocean and therefore influence primary productivity and phytoplank- ton distribution. Figure 4 compares the simulated seasonal MLD with observations (Kara et al., 2002). The simulated MLD has been averaged to the grid of the observations for a clearer comparison. The simulated MLD are slightly shallower than observations. The root-mean-square of the difference is $\sim 20 \mathrm{~m}$.

\subsection{Primary production and coccolithophore distribution}

In the reference simulation STD, the distribution of total phytoplankton concentration resembles the general pattern of a coastal upwelling, with higher concentrations close to the coast. There is a maximum of $3.5 \mathrm{mg}$ chla $\mathrm{m}^{-3}$ in summer (assuming a chla/ $\mathrm{N}$ ratio of $1.59 \mathrm{mg}$ chla $(\mathrm{mmol} \mathrm{N})^{-1}(\mathrm{Os}-$ chlies and Garçon, 1999) and with respect to the total phytoplankton concentration, $P_{1}+P_{2}$ ), corresponding to the maximum chlorophyll concentration reported for the Mauritanian upwelling (Gabric et al., 1993; Fischer et al., 1996; Morel, 2000).

The relative distribution of coccolithophores and diatoms is the result of the competitive ability of each to grow at different levels of nutrient concentrations. This distribution is thus controlled in the model by the differing PFT parameterisations of the diatoms and coccolithophores, which are based only on the growth rate and nitrate assimilation parameters. The diatoms have a higher growth rate than the coccolithophores for nitrate concentrations greater than $2.7 \mathrm{mmol} \mathrm{NO}_{3} \mathrm{~m}^{-3}$. These conditions occur during the strong upwelling events, i.e. in summer and close to the coast. In contrast, coccolithophores are favoured in water masses relatively more nitrate-depleted, i.e. during winter and away from the coast in summer. The typical succession of phytoplankton communities in upwelling systems is thus a diatom-dominated community during, and in the 


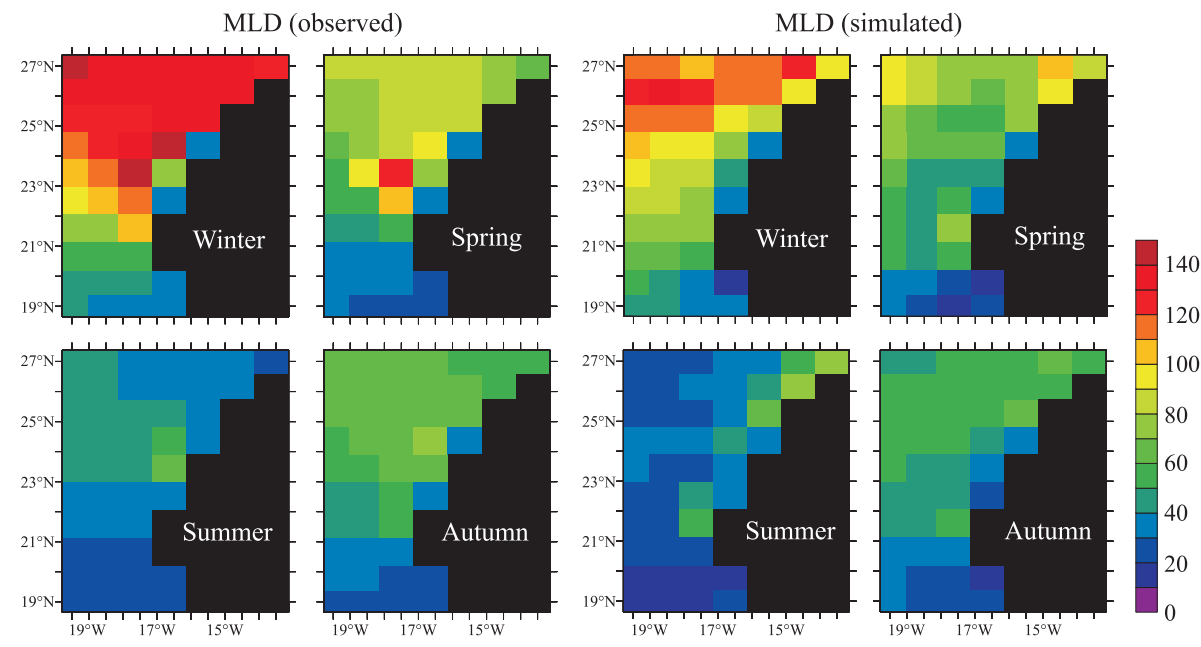

Fig. 4. Seasonal Mixed Layer Depth (MLD), in meters, from the Naval Research Laboratory monthly climatology (left) (Kara et al., 2002), and from the model (right). (seasons: see caption of Fig. 3).

center of, nutrient-rich upwelling, followed by communities dominates by flagellates and coccolithophores during water column stratification (Tilstone et al., 2000; Schiebel et al., 2004).

This sequence of diatoms and coccolithophores is wellreproduced by the model (Fig. 5; STD). The diatoms and coccolithophores show opposite seasonal patterns, with maximum surface concentrations occurring in summer for diatoms and in winter for coccolithophores (1.29 and $0.51 \mathrm{mmol} \mathrm{N} \mathrm{m} \mathrm{N}^{-3}$, respectively). The diatoms distribution shows a strong contrast between high concentrations at the coast, where SSTs are colder and nutrient concentrations higher, and lower concentrations offshore. The coccolithophore distribution is more diffuse, with a maximum more offshore compared to the diatom bloom. The coccolithophore concentration maximum always appears later in the phytoplanktonic sequence associated, in association with the high primary production of the upwelling.

Figure 6 gives the seasonal depth profiles of coccolithophore and phytodetritus concentration from simulation STD and phytodetritus alkenone temperature from simulations STD and DELAY; all at the location of core SU94-11S, which is at the latitude of Cape Blanc (see Fig. 1, and Table 3 for coordinates). It is clear that the coccolithophore production follows a seasonal cycle. The concentration of coccolithophores is twice as much in winter as in summer (Fig. 6a). A similar maximum of coccolithophores in winter is found in observations at station CB offshore Cape Blanc (Köbrich and Baumann, 2004; Köbrich, personal communication). At a Canary Island station, the maximum coccolith flux also occurred in winter, when SSTs are at lowest (Bijma et al., 2001; Sprengel et al., 2002). This seasonal pattern is also visible in the phytodetritus concentration (Fig. 6b). The phytodetritus concentration rapidly increases from the sur-

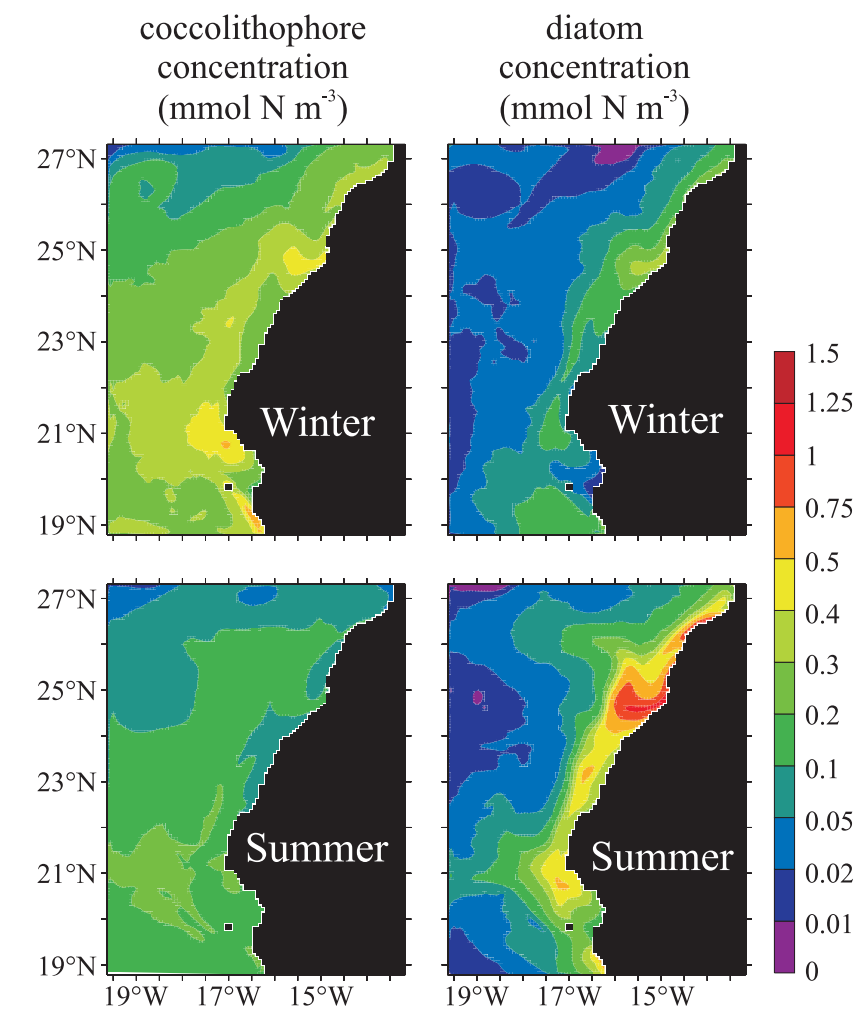

Fig. 5. Simulated (STD) distributions of coccolithophore (left column) and diatom (right column) concentration $\left(\mathrm{mmol} \mathrm{N} \mathrm{m}{ }^{-3}\right)$ in winter (top row) and summer (bottom row) at the sea surface.

face to $\sim 100 \mathrm{~m}$ depth, before slowly decreasing with depth due to remineralization.

The vertical distribution of the coccolithophores at the location of core SU94-11S (Fig. 6a) shows a maximum concentration over the first $30 \mathrm{~m}$ in winter, spring and summer, 
Table 3. Comparison between alkenone-derived SSTs, AVHRR Pathfinder Global 9 km Pentad SST Climatology (PODAAC, 2001), simulated annual mean SSTs and simulated (STD) alkenone IPTs, for core sites off the Northwest African margin (all temperatures in ${ }^{\circ} \mathrm{C}$ ). The $\mathrm{U}_{37}^{K^{\prime}}$ values are as measured in coretop sediments and given in Sicre et al. (2000). The alkenone-derived SSTs are from using the Müller et al. (1998) calibration.

\begin{tabular}{|c|c|c|c|c|c|c|c|c|c|}
\hline Reference & Core site & \multicolumn{2}{|c|}{ Location } & Depth (m) & $\mathrm{U}_{37}^{K^{\prime}}$ & $\operatorname{SST}\left(\mathrm{U}_{37}^{K^{\prime}}\right)$ & SST (AVHRR) & SST (model) & IPT (model) \\
\hline$"$ & GIK12326-3 & $23^{\circ} 18 \mathrm{~N}$ & $17^{\circ} 25 \mathrm{~W}$ & 1046 & 0.71 & 20.2 & 20.1 & 20.9 & 19.4 \\
\hline$"$ & SU94-21S & $24^{\circ} 53 \mathrm{~N}$ & $16^{\circ} 31 \mathrm{~W}$ & 750 & 0.75 & 21.4 & 20.4 & 19.8 & 18.7 \\
\hline$"$ & SU94-15S & $23^{\circ} 44 \mathrm{~N}$ & $17^{\circ} 16 \mathrm{~W}$ & 1000 & 0.74 & 21.1 & 20.3 & 20.6 & 19.0 \\
\hline 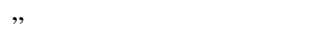 & SU94-11S & $21^{\circ} 29 \mathrm{~N}$ & $17^{\circ} 57 \mathrm{~W}$ & 1200 & 0.73 & 20.8 & 20.0 & 20.1 & 18.9 \\
\hline$"$ & SU94-7S & $21^{\circ} 11 \mathrm{~N}$ & $18^{\circ} 52 \mathrm{~W}$ & 3010 & 0.75 & 21.4 & 20.7 & 20.3 & 18.8 \\
\hline
\end{tabular}
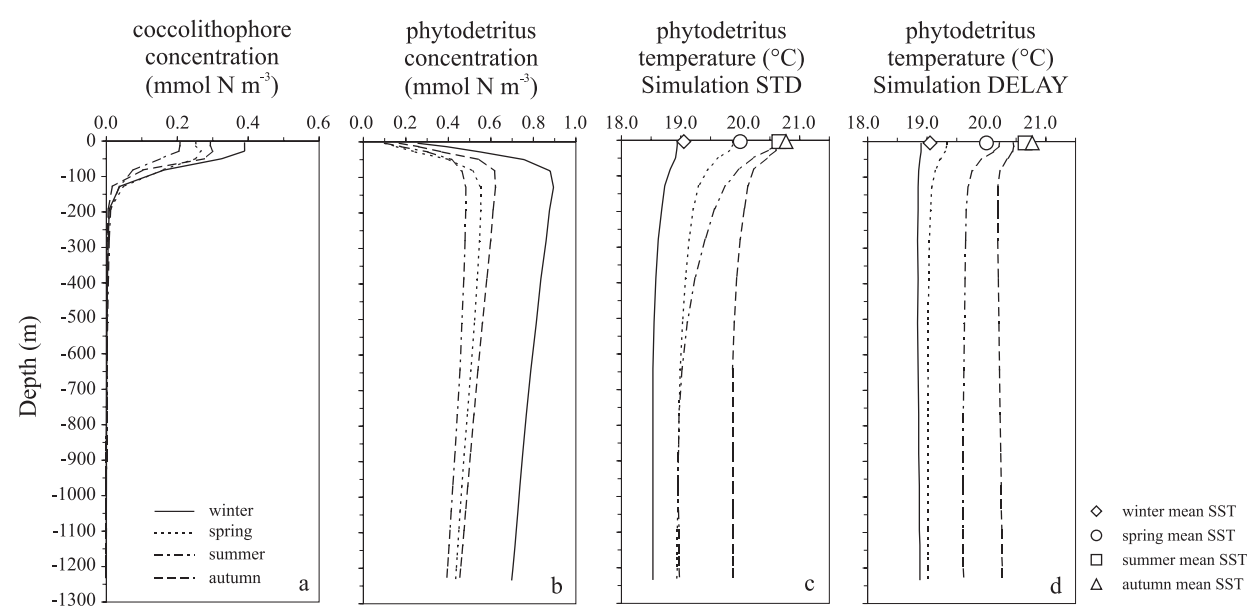

Fig. 6. Seasonal depth profiles at location of core SU94-11S: coccolithophore concentration from simulation STD (a), phytodetritus concentration from simulation STD (b), phytodetritus alkenone temperature from simulation STD (c), and phytodetritus alkenone temperature from simulation DELAY (d); winter (solid line), spring (dotted line), summer (dashed-dotted line) and autumn (dashed line). In (c) and (d) simulated seasonal mean SSTs are also indicated (see legend).

and over the first $50 \mathrm{~m}$ in autumn. It then rapidly decreases to zero at $\sim 200 \mathrm{~m}$. According to this distribution, $\sim 60 \%$ of the coccolithophorid mass is located in the upper $50 \mathrm{~m}$. Time series of coccolithophore standing stocks and taxonomic compositions at the Bermuda Atlantic Hydrostation "S", near the BATS station, have shown that coccolithophore cell densities were highest in the upper $50 \mathrm{~m}$ and decreased rapidly below $100 \mathrm{~m}$ (Haidar and Thierstein, 2001). They also indicate that E. huxleyi can present local maximum densities from the surface until $50 \mathrm{~m}$ and be the dominant coccolithophore species down to $200 \mathrm{~m}$.

\subsection{Temperature record}

3.3.1 Temperature recorded by phytodetritus in the water column

In the reference simulation STD, the phytodetritus alkenone temperatures at the surface are similar to the SSTs (Fig. 6c), which is consistent with the fact that the coccolithophore alkenone temperature always reflects the surrounding water temperature. The phytodetritus alkenone temperature then decreases to the depth of maximum phytodetritus concentration, reflecting the progressive accumulation of deeper and colder phytodetritus production by the coccolithophores. This temperature decrease is $\sim 0.8^{\circ} \mathrm{C}$ in spring and autumn. Below the maximum phytodetritus concentration depth, the alkenone temperature carried by the phytodetritus pool slightly decreases in autumn, winter and spring (around 

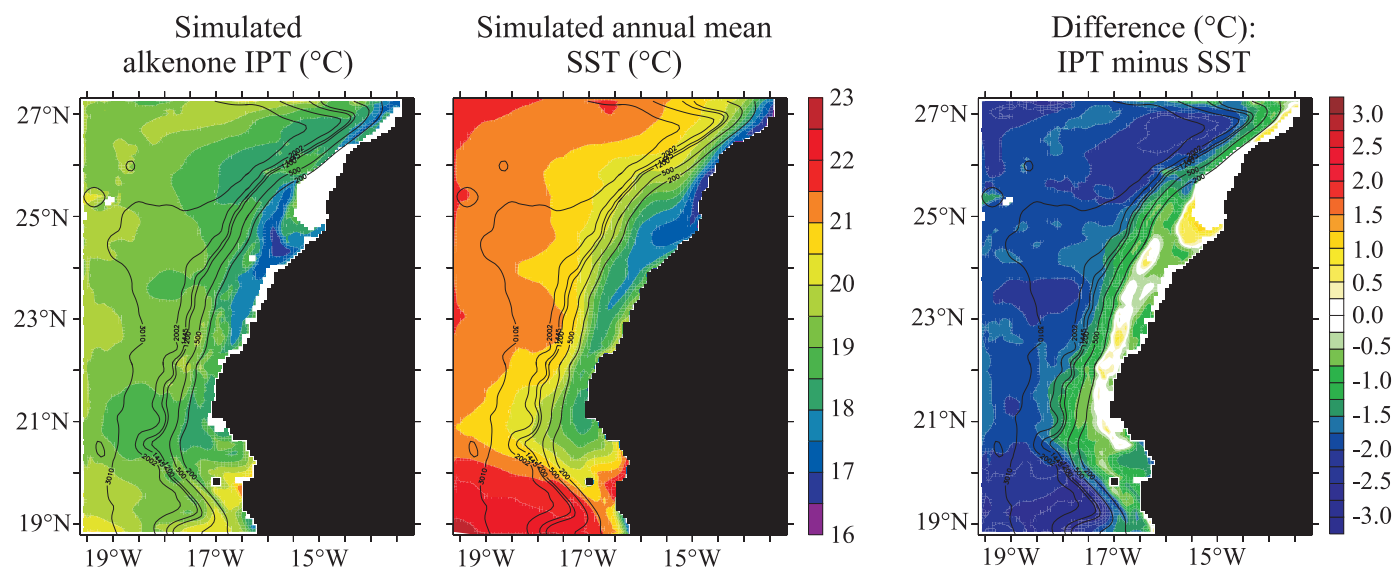

Fig. 7. Simulated (STD) alkenone IPT (left), simulated (STD) annual mean SST (centre), and their difference (first minus second; right) (all in ${ }^{\circ} \mathrm{C}$ ). Solid lines show the bathymetry with isobaths at 200, 500, 1200, 1445, 2000, and $3000 \mathrm{~m}$.

$0.2^{\circ} \mathrm{C}$ from $\sim 100 \mathrm{~m}$ to the bottom) and drops $\sim 1^{\circ} \mathrm{C}$ in summer. We think that these variations at great depth are due to the unequal quantity of phytodetritus reaching there, in relation to the intensity of primary production events. In summer, the high primary production events are associated with cold water filaments, whereas lower production periods are associated with warmer SSTs. There exists therefore a bias toward colder temperatures, due to the more important export of material at depth during upwelling events. This bias is less pronounced in winter, since SSTs of nutrient-rich upwelling filaments and offshore waters are more homogeneous.

In the case of simulation DELAY, given the increased inertia of the temperature record in the coccolithophore pool, phytodetritus alkenone temperature profiles are more homogeneous (Fig. 6d). The winter profile of phytodetritus temperature is constant from the surface to the bottom. In spring, summer and autumn, the phytodetritus alkenone temperatures at the surface are colder than the corresponding seasonal mean SSTs, with a maximum difference of $0.6^{\circ} \mathrm{C}$ in spring. For these three seasons, the phytodetritus temperature then decreases a maximum $0.6^{\circ} \mathrm{C}$ by $\sim 100 \mathrm{~m}$. Below this depth, the temperatures are constant. Because the alkenone temperature record of the coccolithophores is changed only during their growing phase, it induces inertia in their response to water temperature variations. The alkenone temperature signal can then be smoothed by the lateral advection and vertical mixing of the coccolithophores. The coccolithophores at depth also have warmer alkenone temperatures compared to simulation STD, because their growth rate is reduced compared to the surface and they are mixed with pools coming from the warm superficial layers.

\subsubsection{Temperature record in sediments}

Figure 7 shows the simulated (STD) alkenone IPTs and annual mean SSTs and the difference between the two. The lowest IPTs are located on the continental shelf, north of
Cape Blanc, with a minimum of $16.8^{\circ} \mathrm{C}$. They then generally increase offshore. The area south of Cape Blanc is an exception, with high IPTs on the shelf, which we attribute to the particularly warm SSTs close to the coast. The map of the temperature differences (Fig. 7, right) shows that the IPTs are colder than the annual mean SSTs, with an average difference of $1.6^{\circ} \mathrm{C}$ on the modelled region.

Table 3 shows the alkenone temperatures of coretop sediments for different core sites off Mauritania, as well as the climatological annual mean SSTs, simulated annual mean SSTs and simulated alkenone IPTs. The core locations are also shown on Fig. 1. Table 3 clearly shows that at the depth of core locations, between $750 \mathrm{~m}$ and $3000 \mathrm{~m}$, the simulated alkenone IPTs are colder than the simulated annual mean SSTs by $1.1^{\circ} \mathrm{C}$ to $2.3^{\circ} \mathrm{C}$. In contrast, the alkenone temperatures of coretop sediments at these core locations, using the Müller et al. (1998) calibration, are similar or warmer than the annual mean SSTs.

\section{Discussion}

The processes potentially responsible for the temperature difference between the simulated alkenone IPTs and the annual mean SSTs are: (1) the depth of alkenone production; (2) the seasonality of coccolithophore production; (3) the lateral advection and vertical transport of the phytodetritus; and (4) the resuspension and transport of sediments. If we introduce the possibility of inertia in the alkenone production (simulation DELAY) and therefore a delay in the response of the coccolithophores to the changing growing conditions, then the lateral advection of the coccolithophores at the surface may also play a role in the final sedimentary temperature record. We discuss the influence of each of these aspects and then the implications for the interpretation of the alkenone temperatures of the coretop sediments. 
4.1 Lateral advection and vertical transport of phytodetritus

The high and constant sinking velocity set in the model $\left(200 \mathrm{~m} \mathrm{~d}^{-1}\right)$ is responsible for fast export of the organic matter (the detritus pool) from the surface to the sea floor. As a consequence, the lateral advection of particles in the water column seems to play a minor role in the temperature signal mixing. In order to evaluate this lateral advection component, we performed a sensitivity test, "STD+NOADV" in which the advection term applied to the detritus pool was disabled. The result was that there was little change in the biogeochemical distribution and primary production location because the detritus pool was still remineralising progressively at depth, and sustains the correct nutrient recycling budget for the upwelling. The IPT obtained from this sensitivity test is similar to the reference simulation, with only minor temperature variations, lower than $0.2^{\circ} \mathrm{C}$ (not shown). We thus conclude that the lateral advection of the phytodetritus has no impact on the temperature signal when the sinking velocity is fast and constant.

Nevertheless, some studies suggest that vertical sinking velocities are low in the surface mixed layer and increase with depth, due to aggregation processes (Kriest and Evans, 1999; Berelson, 2002; Klaas and Archer, 2002; Kriest, 2002). A relatively low sinking velocity in the surface layer would therefore favour transport of the detritus pool by lateral advection. This would mean an efficient transport of particles produced in cold onshore waters to more offshore locations, i.e. over the slope or abyssal plain. Therefore, we performed a sensitivity test, "STD+SINKING", considering a sinking rate, $V_{s}\left(\mathrm{~m} \mathrm{~d}^{-1}\right)$, of $5 \mathrm{~m} \mathrm{~d}^{-1}$ in the upper $50 \mathrm{~m}$, followed by an exponential increase with a scale-height of $200 \mathrm{~m}$, with a maximum sinking rate of $200 \mathrm{~m} \mathrm{~d}^{-1}$ at the bottom:

$V_{S}=\max \left[5 ; 5+195\left(1-e^{-\frac{z-50}{200}}\right)\right]$

The IPTs produced by this lower sinking rate are different from the reference simulation only south of $22^{\circ} \mathrm{N}$ (not shown). There, the IPTs are $\sim 0.4^{\circ} \mathrm{C}$ colder than for the reference simulation STD, with a maximum cooling of $1^{\circ} \mathrm{C}$ in a localized area. This means that in this southern area the simulated IPTs are between 1.5 and $3^{\circ} \mathrm{C}$ colder than the annual mean SST. We conclude that lower sinking rates have an impact in regions where SST gradients are stronger. The particulate material produced in the cold central upwelling area is advected offshore in the surface layer and contributes to the sedimentation on the continental slope, where SSTs are already warmer. It seems that north of $22^{\circ} \mathrm{N}$ this effect is negligible because the strong currents are mostly parallel to the slope and therefore generally parallel to the SST isotherms.

\subsection{Sediment resuspension}

Because of the distinction made in the model between detritus (D) and suspended sediments (S), it is possible to keep track of the direct detritus flux at the bottom, separately from the sediment resuspension and transport. There exists therefore a difference between the final sediment accumulation and the flux over time of the detritus at the bottom. The comparison of the IPT and the alkenone temperature of the total phytodetritus bottom flux provides information on the effect of the resuspension processes.

In the reference simulation STD, the resuspension of sediments on the shelf does not modify the IPTs on the slope (not shown) and only small temperature differences $\left(<0.2^{\circ} \mathrm{C}\right)$ appear on the shelf, due to local redistribution processes. Even if the sediment resuspension in the model contributes to a better budget of the nutrients by enabling their remineralisation in the water column, it does not directly influence the sediment temperature distribution. Nevertheless, given the sedimentary temperature distribution (Fig. 7, left) and the colder IPTs on the shelf, any effective sediment transport from the coast to the slope would contribute to a cooling of the alkenone temperature of the slope sediments and therefore to an increase in the temperature difference between annual mean SSTs and IPTs.

\subsection{Seasonality}

The seasonality of the coccolithophores was shown on the Figs. 5 and 6. Taking as an example the depth profiles at the location of core SU94-11S offshore Cape Blanc (Fig. 6), it appears that the coccolithophores concentration is twice as high in winter than in other seasons. Does this produce a seasonal bias in the IPT? Figure 8 shows, for the same core location, the depth profiles of annual mean water temperature, annual mean phytodetritus alkenone temperature, and the mass-averaged annual mean phytodetritus alkenone temperature, for simulations STD and DELAY. The difference between the two profiles of phytodetritus alkenone temperatures is due to the relative weight of productive periods. At the surface and subsurface, the temperature difference is at a maximum, between 0.6 and $0.8^{\circ} \mathrm{C}$, an indication of the winter influence, as well as the cold, productive filaments in summer. Below $\sim 100 \mathrm{~m}$, the temperature difference is small and constant to the bottom at $\sim 0.2^{\circ} \mathrm{C}$. This is also the temperature difference obtained for the simulation DELAY (Fig. 8b). We think therefore that the seasonality of coccolithophore production has a minor effect on the IPT at this particular location. It is worth noting that Müller and Fischer (2001) also concluded, based on a 4-year sediment trap record of alkenones at station $\mathrm{CB}$ offshore Cape Blanc that the alkenone temperature of coretop sediments was best correlated with the annual mean SST, but for a different reason. Although the alkenone production showed a strong 


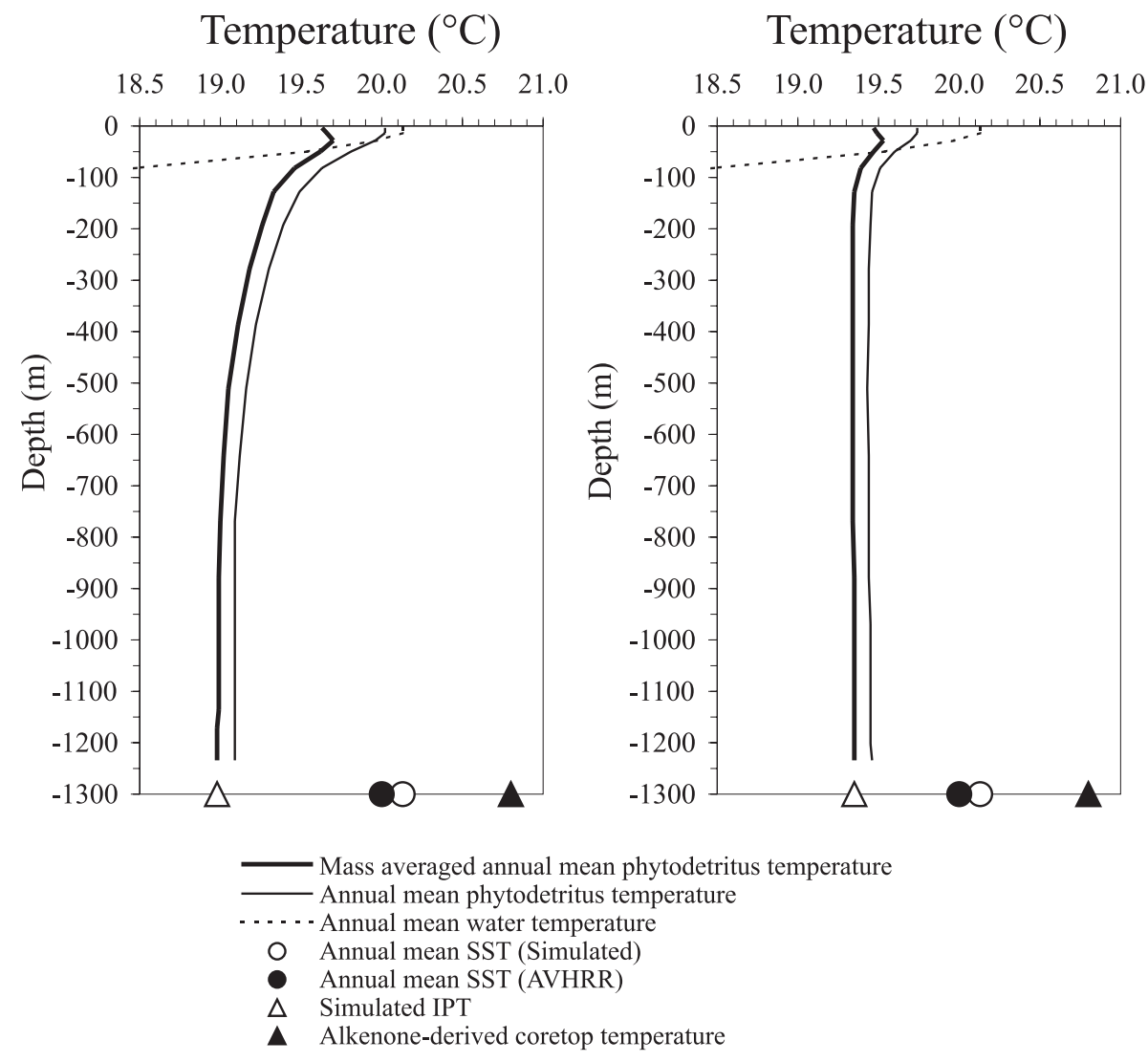

Fig. 8. Depth profiles of annual mean water temperature (dotted line), annual mean phytodetritus alkenone temperature (thin solid line) and mass averaged annual mean phytodetritus alkenone temperature (thick solid line) at location of core SU94-11S for the reference simulation STD (left) and for simulation DELAY (right).

seasonality, the seasonal flux variations were different for each year, leading to an averaged record in sediments.

\subsection{Production depth}

According to the previous discussion, lateral advection of particles, sediment resuspension, and coccolithophore seasonality seem to play only a minor role in the IPT. The sum of all these factors is also not sufficient to explain the temperature discrepancy. Thus, the cause of the temperature difference between the IPT and the annual mean SST is most likely to be found in the production depth, which we are discussing below, or some other missing processes, which we discuss in the next section.

It is apparent in the depth profiles of Figs. 6 and 8 that the decrease of the phytodetritus alkenone temperature in the water column occurs mostly in the first $100 \mathrm{~m}$. Therefore a sensitivity test, "STD+GROWTH", was performed in order to evaluate the impact of coccolithophore growth depth. This sensitivity case is based on the argument that E. huxleyi is at disadvantage at low light levels compared to other phytoplankton groups (Merico et al., 2004). This is implemented in the model by using a lower value for initial slope of the Production-Insolation curve ( $\alpha$ in Table 1 ) of the coccolithophore PFT: $0.015 \mathrm{~W} \mathrm{~m}^{-2}$ instead of $0.025 \mathrm{~W} \mathrm{~m}^{-2}$. As a consequence, the growth rate of coccolithophores is lowered at depth, and the vertically-integrated production may be significantly reduced. In order to compensate for this effect, we also set the maximum growth rate higher, from $0.4 \mathrm{~d}^{-1}$ to $0.5 \mathrm{~d}^{-1}$, so that coccolithophores were favoured in the surface ocean.

This variation of coccolithophore PFT leads to a slightly shallower coccolithophore distribution. At the location of core SU94-11S, 70\% of the coccolithophore mass becomes located in the upper $50 \mathrm{~m}$, compared to $\sim 60 \%$ in the reference simulation STD. However, setting the maximum growth rate higher did not completely compensate for the decrease of production at depth, so that coccolithophore concentrations are generally also lower at the sea surface.

The resulting IPT is slightly warmer than the reference simulation, which also means closer to the simulated annual mean SSTs. In a simulation combining this coccolithophore PFT variation with the inertia in temperature adaptation of coccolithophores (simulation DELAY+GROWTH), the IPTs are still $\sim 1^{\circ} \mathrm{C}$ colder than the annual mean SST (Fig. 9). This temperature difference is still significant since it appears to 


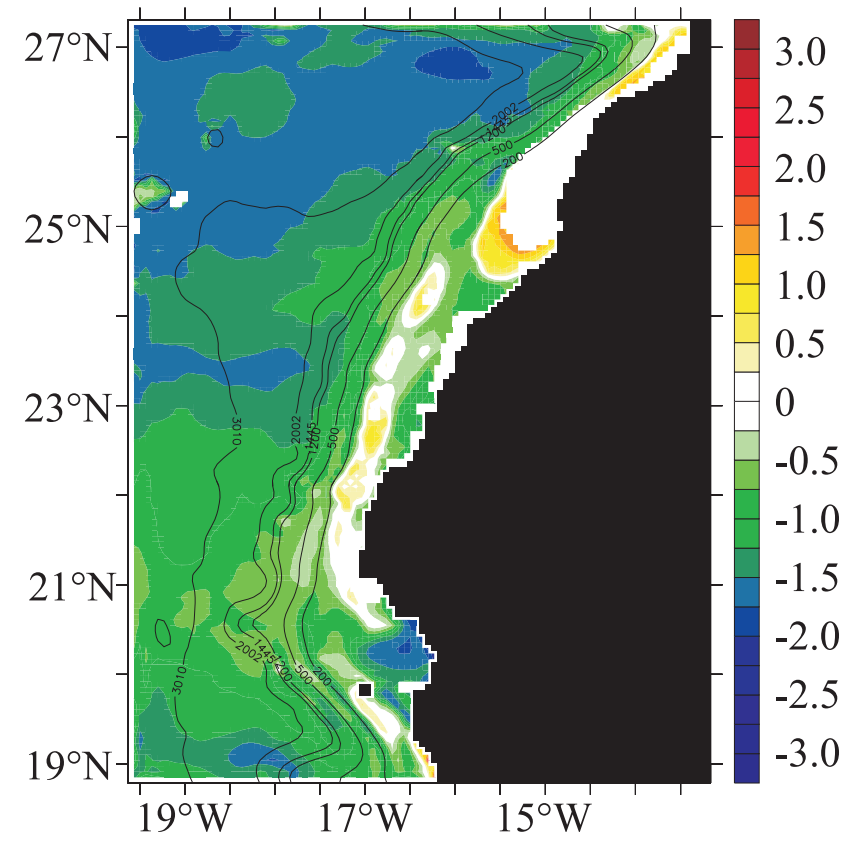

Fig. 9. Temperature difference $\left({ }^{\circ} \mathrm{C}\right)$ between the simulated alkenone IPT and the simulated annual mean SST for simulation DELAY+GROWTH (see text for simulation description).

be systematic over the study area. The reason appears to be a still-significant contribution by the coccolithophore populations present in the lower part of the MLD to the phytodetritus alkenone temperature record.

From the preceding, it seems difficult to force the coccolithophore population to be localised only in the top $30 \mathrm{~m}$ without modifying the equilibrium with the other phytoplanktonic PFTs. With our coccolithophore PFT regarded as representing all coccolithophores, our simulated coccolithophore distribution is temporally and spatially correct. The distribution of the alkenone production in the coccolithophore population itself thus appears to be the important question. As already mentioned, the main alkenone producer species $E$. huxleyi can be present and be the main contributor to the coccolithophore assemblage down to $100 \mathrm{~m}$ or deeper. We think therefore that the implicit assumption made in the model, that $E$. huxleyi can represent all coccolithophores, is valid in this work.

The alkenone distribution in the surface ocean is most probably a matter of physiological factors. The exact details of alkenone production, during coccolithophore growth, are unfortunately not well known. Batch culture experiment have demonstrated that the cell alkenone content, as well as the $\mathrm{U}_{37}^{K^{\prime}}$, may be significantly affected by environmental conditions like nutrient or light stress, as well as stationary or exponential growth phases (e.g. Epstein et al., 1998; Prahl et al., 2003). The quantity of alkenone per cell may vary as a function of growth conditions and therefore be unequal from one habitation depth to another. In order to answer this ques-

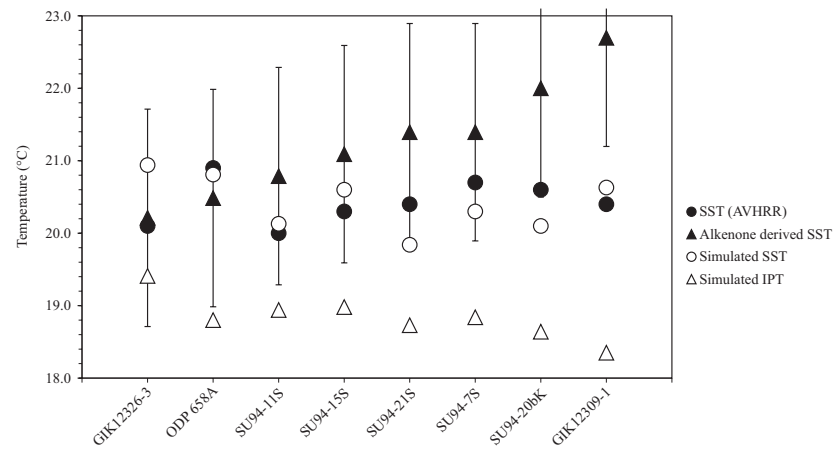

Fig. 10. Annual mean SSTs and sedimentary alkenone temperatures for the cores given in Table 3: alkenone temperatures of coretop sediment using the Müller et al. (1998) calibration (black triangles) and assuming an error bar of $\pm 1.5^{\circ} \mathrm{C}$; annual mean SSTs from the AVHRR Pathfinder Global $9 \mathrm{~km}$ Pentad SST Climatology (PODAAC, 2001) (black circles); simulated annual mean SSTs (white circles); simulated (STD) alkenone IPT (white triangles). Cores are ordered by increasing $\mathrm{U}_{37}^{K^{\prime}}$ (see Table 3 ).

tion, we suggest further studies of the physiological factors involved in alkenone production and turnover.

\subsection{Calibration and interpretation of the $\mathrm{U}_{37}^{K^{\prime}}$ index}

Since the alkenone temperature of coretop sediments is usually associated with annual mean SST, the previous sections have tried to understand the reason why our model results always have a temperature difference between the IPT and annual mean SST. We discussed the importance of production depth. As the coccolithophore distribution in the simulations seem correct, we concluded that the alkenone production itself may not be simply proportional to the coccolithophore biomass. We also concluded that since the details of alkenone production are not well known, our model may still be correctly representing the distribution of alkenone distribution. In this section, we discuss the case where the model produces the correct IPTs and the meaning of its mismatch with the alkenone temperatures of coretop sediments.

For each core described in Table 3, Fig. 10 displays the different temperatures obtained from alkenone measurements, climatology and simulations (STD). It shows that the annual mean SSTs from the model and the AVHRR Pathfinder Global 9 km Pentad SST climatology (PODAAC, 2001) are similar, which implies the model is simulating the upwelling well. Despite the large geographical distribution of the cores (see Fig. 1), the annual mean SSTs do not vary much, and range between 19.8 and $20.9^{\circ} \mathrm{C}$ for the simulation and are even closer (between 20.0 and $20.9^{\circ} \mathrm{C}$ ) for the AVHRR Pathfinder Global $9 \mathrm{~km}$ Pentad SST climatology (PODAAC, 2001). Using the Müller et al. (1998) calibration, the $U_{37}^{K^{\prime}}$ values for these cores imply alkenone temperatures ranging from 20.2 to $22.7^{\circ} \mathrm{C}$. However, it should be noted that the standard error is estimated (Müller et al., 1998) at $\pm 1.5^{\circ} \mathrm{C}$ 
(the bars in Fig. 10). Within this error bar, the alkenone temperatures of the coretop sediments are in agreement with the annual mean SSTs. Two exceptions are the two cores having the highest $\mathrm{U}_{37}^{K^{\prime}}$. For these two cores, SU94-20bK $\left(25^{\circ} 1 \mathrm{~N}\right.$, $\left.16^{\circ} 9 \mathrm{~W}\right)$ and GIK12309-1 $\left(26^{\circ} 0 \mathrm{~N}, 15^{\circ} 7 \mathrm{~W}\right)$, the alkenone temperatures are higher than the annual mean SSTs. The simulated IPTs associated with the cores presented in Table 3 and Fig. 10 range from 18.3 to $19.4^{\circ} \mathrm{C}$. They show the same trend as the simulated annual mean SSTs but are 1.1 to $2.3^{\circ} \mathrm{C}$ colder.

If we assume the alkenone index calibration is correct, the mismatch between the alkenone temperature of coretop sediments and the simulated IPT may stem from either a missing process in the modelling, or a misinterpretation of the alkenone temperature.

One possible missing process is a diagenetic modification of the alkenone ratio in the sediments. After sediment burial a differential degradation of di- and tri-unsaturated alkenone compounds could lead to an increase in the $\mathrm{U}_{37}^{K^{\prime}}$, causing an apparent warming in the sediment alkenone temperature record. Some studies argue for a possible modification of the original temperature signal in the sediments (Hoefs et al., 1998; Gong and Hollander, 1999; Rontani et al., 2005), whereas other studies conclude that there is no diagenetic effect on the temperature record (e.g. Grimalt et al., 2000; Harvey, 2000). Diagenetic bias thus remains only a hypothesis.

A second possible missing process that could explain the temperature mismatch is contamination by allochtonous material. A location could be contaminated by allochthonous transported material having a relatively-warmer alkenone temperature record. The simulated IPT then might be the "cold" temperature of the location and the alkenone temperature the result of the "warm" contamination. It is hard to say where the origin of this hypothetical "warm" allochthonous sedimentary material might be since the most-likely material would come from the continental shelf, which is an area where we expect the IPT, and thus the alkenone temperature, to be colder.

Another possible mismatch explanation would be a misinterpretation of the alkenone temperature of coretop sediments due to the age of the alkenones. Previous studies have shown that the alkenones were $1000-4500$ years and $\sim 1000$ years older than the co-occurring foraminifera in Namibian slope sediments (Mollenhauer et al., 2003) and Chilean margin sediments (Mollenhauer et al., 2005), respectively. However, no age differences were found between the alkenones and contemporary foraminifera of a core in Northwest Africa $\left(\right.$ GeoB5546-2, 27.53 $\left.{ }^{\circ} \mathrm{N}, 13.73^{\circ} \mathrm{W}\right)$, just north of our study area (Mollenhauer et al., 2005). Mollenhauer et al. (2005) suggest that the physical depositional settings, such as shelf width, or morphologic depressions may play a role in the age control of the sediment components. Core GeoB55462, although in the Northwest African coastal upwelling system, is not facing a large continental shelf. In contrast, the cores described in Table 3 are facing a large continental shelf, just as in the Namibian slope case. It is thus possible that the alkenones in these cores also have an age offset. If this is the case, the alkenone temperature is an average over an unknown time span extending back from the present day. The simulated IPT though is only for present day. As the alkenone temperatures are warmer than the simulated IPTs, the present day alkenone pool would have to have been mixed with a "warmer" and older alkenone pool. Appendix A estimates these past temperatures assuming an alkenone age offset and a decreasing exponential contribution of older sediments to the coretop. In the case of core SU94-11S, offshore Cape Blanc, the IPT at $6 \mathrm{ka}$ BP is estimated to have been between $2.8^{\circ} \mathrm{C}$ and $5.7^{\circ} \mathrm{C}$ warmer than the present day IPT. These estimates are speculative but could be tested by measuring the age of the alkenones in slope sediments facing the large Northwest African continental shelf.

\section{Conclusions}

We developed a coupled physical-biogeochemical model to simulate the production, transport and sedimentation of the alkenone temperature proxy in the Northwest African upwelling system, between $19^{\circ} \mathrm{N}$ and $27^{\circ} \mathrm{N}$. We conclude that the alkenone temperature record of the slope sediments (between $1000 \mathrm{~m}$ and $3000 \mathrm{~m}$ depth) are between 1.1 and $2.3^{\circ} \mathrm{C}$ colder than present-day annual mean SSTs. This offset is opposite to the one identified by Conte et al. (2006) in a global calibration of the alkenone index. This suggests that the use of the $\mathrm{U}_{37}^{K^{\prime}}$ index to reconstruct past annual mean SSTs is problematic, because the processes responsible for its record are not fully understood. Nevertheless, the temperature discrepancy we found seems to be mostly due to the production depth of the coccolithophores, with minor contributions from seasonality and lateral advection. No process that could possibly explain the significant positive offset identified by Conte et al. (2006) could be found with our modelling study, unless a possible mixing with mid-Holocene material. These results are based on the assumption that the amount of alkenones produced is proportional to the coccolithophore population, which varies with depth. This is an assumption about physiology and further research in this area would thus be of great benefit.

\section{Appendix A}

We estimate here the past temperature of sedimentary fluxes, based on the simulated present day IPT, the alkenone temperature of coretop sediments, and assuming an age offset between the alkenones and the co-occurring foraminiferal. Our general assumption is that the surface sediment alkenones are the result of mixing with older alkenones, but we make more specific assumptions. 
Assumption \#1: The relative contribution of each time period to the coretop sediments, $\alpha_{S}(t)$, follows a decreasing exponential:

$\alpha_{S}(t)=\frac{1}{\beta} \exp \left(-\frac{t}{\beta}\right)$

where $t$ is the time $\mathrm{BP}(\mathrm{ka})$, and $\beta$ is the age offset of the coretop alkenones $(\mathrm{ka})$. The degree of mixing of sediments is the result of different processes like resuspension or bioturbation as well as sedimentation rate. These processes were not always constant over the past period. Nevertheless, in order to make the calculations simple, we assume constant production and mixing rates. We also assume an infinite sediment thickness, an approximation that facilitates the calculation and the reason for the integrations from 0 to infinity that follow.

Let $A_{S}(t)$ be the apparent age of the sediments and $A_{i}(t)=t$ be the age of the instantaneous sedimentary flux. We can verify that the apparent age of the coretop sediments, $A_{S}(0)$ is equal to the age offset:

$$
\begin{aligned}
& A_{S}(t=0)=\int_{0}^{\infty} A_{i}(t) \alpha_{S}(t) d t \\
& =\int_{0}^{\infty} \frac{t}{\beta} \exp \left(-\frac{t}{\beta}\right) d t=\beta
\end{aligned}
$$

Let $T_{S}(t)$ be the alkenone temperature of the sediments and $T_{i}(t)$ be the alkenone temperature of the instantaneous sedimentary flux, which is also the IPT.

The alkenone temperature of the coretop sediments, $T_{S}(0)$, is the mass-weighted temperature accumulated over time and can thus be expressed as:

$T_{S}(0)=\int_{0}^{\infty} T_{i}(t) \alpha_{S}(t) d t$

Assumption \#2: The IPT evolved linearly over a certain past period $(\theta$, in $\mathrm{ka})$, and so can be expressed as:

$T_{i}(t)=T_{i}(0)+\frac{T_{i}(\theta)-T_{i}(0)}{\theta} t$

Using Eqs. (A3) and (A4), we obtain:

$T_{S}(0)=$

$\int_{0}^{\infty}\left(T_{i}(0)+\frac{T_{i}(\theta)-T_{i}(0)}{\theta} t\right) \frac{1}{\beta} \exp \left(-\frac{t}{\beta}\right) d t$

$T_{S}(0)=T_{i}(0) \int_{0}^{\infty} \frac{1}{\beta} \exp \left(-\frac{t}{\beta}\right) d t$

$+\frac{T_{i}(\theta)-T_{i}(0)}{\theta} \int_{0}^{\infty} \frac{t}{\beta} \exp \left(-\frac{t}{\beta}\right) d t$

It can be easily demonstrated that:

$\int_{0}^{\infty} \frac{1}{\beta} \exp \left(-\frac{t}{\beta}\right) d t=1$ and

$$
\int_{0}^{\infty} \frac{t}{\beta} \exp \left(-\frac{t}{\beta}\right) d t=\beta
$$

Equation (A6) then becomes:

$$
\begin{aligned}
& T_{S}(0)=T_{i}(0)+\left(T_{i}(\theta)-T_{i}(0)\right) \frac{\beta}{\theta} \\
& \frac{T_{i}(\theta)-T_{i}(0)}{\theta}=\frac{T_{S}(0)-T_{i}(0)}{\beta}
\end{aligned}
$$

Substituting, Eq. (A4) becomes:

$$
T_{i}(t)=T_{i}(0)+\left(T_{S}(0)-T_{i}(0)\right) \frac{t}{\beta}
$$

Equation (A11) expresses the IPT at any time, $T_{i}(t)$, as a function of the present day IPT, $T_{i}(0)$. The terms are obtained from the simulations, the alkenone temperature of the coretop sediments, $T_{S}(0)$, and the age offset of the coretop alkenones.

Before proceeding to apply this numerically, it is important to be able to evaluate the relative contribution of sediments pools with respect to their age. This can be done with $R_{S}(t)$, the proportion of sediments younger than $t$ contributing to the coretop sediments.

$$
\begin{aligned}
& R_{S}(t)= \\
& \int_{0}^{t} \alpha_{S}(t) d t=\int_{0}^{t} \frac{1}{\beta} \exp \left(-\frac{t}{\beta}\right) d t=1-\exp \left(-\frac{t}{\beta}\right)
\end{aligned}
$$

Applying Eqs. (A11) and (A12) numerically using core SU94-11S as an example, we substitute in:

$\mathrm{T}_{i}(0)=18.9^{\circ} \mathrm{C}$, the simulated IPT, and

$\mathrm{T}_{S}(0)=20.8^{\circ} \mathrm{C}$, the alkenone temperature of the coretop sediments.

Then, if we assume an alkenone age offset of $\beta=4 \mathrm{ka}$, we obtain $T_{i}(6 \mathrm{ka})=21.75^{\circ} \mathrm{C}$, with $R_{S}(6 \mathrm{ka})=78 \%$. If we assume an alkenone age offset of $\beta=2 \mathrm{ka}$, we obtain $T_{i}$ $(6 \mathrm{ka})=24.6^{\circ} \mathrm{C}$, with $R_{S}(6 \mathrm{ka})=95 \%$.

These results show that the alkenone age offset (if any), which is directly related to the degree of sediment mixing, is an important factor in estimating the past temperatures. In the case of core SU94-11S, offshore Cape Blanc, Mauritania, the temperature difference between present day and $6 \mathrm{ka} \mathrm{BP}$, can be estimated to be between $2.8^{\circ} \mathrm{C}$ and $5.7^{\circ} \mathrm{C}$.

Acknowledgements. This work was funded by the Deutsche Forschungsgemeinschaft through a Fellowship of the DFG Research Center Ocean Margins (RCOM). This work benefited from helpful comments and reviews by M. Schulz and A. Paul. The author thanks D. Thresher as well as the two other anonymous referees for their helpful comments. No. RCOM0409.

Edited by: J. Bijma 


\section{References}

Andruleit, H., Stäger, S., Rogalla, U., and Cepek, P.: Living coccolithophores in the northern Arabian Sea: ecological tolerances and environmental control, Marine Micropaleontology, 49, 157181, 2003.

Benthien, A. and Müller, P. J.: Anomalously low alkenone temperatures caused by lateral particle and sediment transport in the Malvinas Current region, western Argentine Basin, Deep Sea Res. I, 47, 2369-2393, 2000.

Berelson, W. M.: Particle settling rates increase with depth in the ocean, Deep Sea Res. II, 49, 237-251, 2002.

Bijma, J., Altabet, M., Conte, M., Kinkel, H., Versteegh, G. J. M., Volkman, J. K., Wakeham, S. G., and Weaver, P. P.: Primary signal: Ecological and environmental factors - Report from Working Group 2, Geochem. Geophys. Geosyst., 2, Paper number 2000GC000051, 2001.

Blanke, B., Roy, C., Penven, P., Speich, S., McWilliams, J., and Nelson, G.: Linking wind and interannual upwelling variability in a regional model of the southern Benguela, Geophys. Res. Lett., 29, 2188, doi:10.1029/2002GL015718, 2002.

Blayo, E. and Debreu, L.: Adaptive mesh refinement for finitedifference ocean models: First experiments, J. Phys. Ocean., 29, 1239-1250, 1999.

Blom, G. and Aalderink, H.: Calibration of three resuspension/sedimentation models, Wat. Sci. Tech., 37, 41-49, 1998.

Bory, A., Jeandel, C., Leblond, N., Vangriesheim, A., Khripounoff, A., Beaufort, L., Rabouille, C., Nicolas, E., Tachikawa, K., Etcheber, H., and Buat-Ménard, P.: Downward particle fluxes within different productivity regimes off the Mauritanian upwelling zone (EUMELI program), Deep Sea Res. I, 48, 22512282, 2001.

Brassell, S. C., Eglington, G., Marlow, I. T., Pflaumann, U., and Sarnthein, M.: Molecular stratigraphy: a new tool for climatic assessment, Nature, 320, 129-133, 1986.

Chai, F., Dugdale, R. C., Peng, T.-H., Wilkerson, F. P., and Barber, R. T.: One-dimensional ecosystem model of the equatorial Pacific upwelling system. Part I: model development and silicon and nitrogen cycle, Deep Sea Res. II, 49, 2713-2745, 2002.

Conkright, M. E., Locarnini, R. A., Garcia, H. E., O’Brien, T. D., Boyer, T. P., Stephens, C., and Antonov, J. I.: World Ocean Atlas 2001: Objective Analyses, Data Statistics, and Figures, CDROM Documentation. National Oceanographic Data Center, Silver Spring, MD, 17 pp., 2002.

Conte, M. H., Eglinton, G., and Madureira, L. A. S.: Long-chain alkenones and alkyl alkenoates as palaeotemperature indicators: their production, flux and early sedimentary diagenesis in the Eastern North Atlantic, in: Advances in Organic Geochemistry, edited by: Eckardt, C. B., Maxwell, J. R., Larter, S. R., and Manning, D. A. C., 1991; Org. Geochem., 19, 287-298, 1992.

Conte, M. H. and Eglinton, G.: Alkenone and alkenoate distribution within the euphotic zone of the eastern North Atlantic: correlation with production temperature, Deep Sea Res. I, 40, 19351961, 1993.

Conte, M. H., Thompson, A., Lesley, D., and Harris, R. P.: Genetic and physiological influences on the alkenone/alkenoate versus growth temperature relationship in Emiliana huxleyi and Gephyrocapsa oceanica, Geochim. Cosmochim. Acta, 62, 5168, 1998.

Conte, M. H., Sicre, M.-A., Rühlemann, C., Weber, J. C., Schulte,
S., Schulz-Bull, D., and Blanz, T.: Global temperature calibration of the alkenone unsaturation index $\left(\mathrm{U}_{37}^{K^{\prime}}\right)$ in surface waters and comparison with surface sediments, Geochem. Geophys. Geosyst., 7(2), doi:10.1029/2005GC001054, 2006.

da Silva, A. M., Young, C. C., and Levitus, S.: Atlas of surface marine data, vol. 1-5, NOAA Atlas NESDIS 6-10, 1994.

Debreu, L.: Raffinement adaptatif de maillage et méthode de zoom - application aux modèles d'océan, $\mathrm{PhD}$ thesis, Université Joseph Fourier, Grenoble, 2000.

Debreu, L. and Vouland, C.: AGRIF: Adaptive Grid Refinement In Fortran, available on http://www-lmc.imag.fr/IDOPT/AGRIF/ index.html, 2003.

Di Lorenzo, E., Miller, A. J., Neilson, D. J., Cornuelle, B. D., and Moisan, J. R.: Modelling observed California Current mesoscale eddies and the ecosystem response, Int. J. Remote Sensing, 25, 1307-1312, 2004.

Eppley, R. W., Rogers, J. N., and McCarthy, J. J.: Half-saturation constants for uptake of nitrate and ammonium by marine phytoplankton, Limn. and Ocean., 14, 912-920, 1969.

Epstein, B. L., D’Hondt, S., Quinn, J. G., Zhang, J., and Hargraves, P. E.: An effect of dissolved nutrient concentrations on alkenonebased temperature estimates, Paleoceanography, 13, 122-126, 1998.

Epstein, B. L., D'Hondt, S., and Hargraves, P. E.: The possible metabolic role of $\mathrm{C}_{37}$ alkenones in Emiliana huxleyi, Org. Geochem., 32, 867-875, 2001.

Fernandez, E., Balch, W. M., Maranon, E., and Holligan, P. M.: High rates of lipid biosynthesis in cultured, mesocosm and coastal populations of the coccolithophore Emiliania huxleyi, Mar. Ecol. Prog. Ser., 114, 13-22, 1994.

Fischer, G., Donner, B., Ratmeyer, V., Davenport, R., and Wefer, G.: Distinct year-to-year particle flux variations off Cape Blanc during 1988-1991: Relation to $\delta^{18} \mathrm{O}$-deduced sea-surface temperatures and trade winds, J. Marine Res., 54, 73-98, 1996.

Fütterer, D. K.: The modern upwelling record off Northwest Africa, in: Coastal Upwelling: Its Sedimentary Record, Part B: Sedimentary Records of Ancient Coastal Upwelling, edited by: Tiede, J. and Süess, E., 105-121, Plenum, New York, 1983.

Gabric, A. J., Garcia, L., Van Camp, L., Nykjaer, L., Eifler, W., and Schrimpf, W.: Offshore export of shelf production in the Cape Blanc (Mauritania) giant filament as derived from coastal zone color scanner imagery, J. Geophys. Res., 98(C3), 46974712, 1993.

Giraud, X., Bertrand, P., Garçon, V., and Dadou, I.: Modeling d15N evolution: First palaeoceanographic applications in a coastal upwelling system, J. Marine Res., 58, 609-630, 2000.

Giraud, X., Bertrand, P., Garçon, V., and Dadou, I.: Interpretation of the nitrogen isotopic signal variations in the Mauritanian upwelling with a 2D physical-biogeochemical model, Global Biogeochem. Cycles, 17, 1059, 2003.

Gong, C. and Hollander, D. J.: Evidence for differential degradation of alkenones under contrasting bottom water oxygen conditions: Implication for paleotemperature reconstruction, Geochim. Cosmochim. Acta, 63, 405-411, 1999.

Gregg, W. W., Ginoux, P., Schopf, P. S., and Casey, N. W.: Phytoplankton and iron: validation of global three-dimensional ocean biogeochemical model, Deep Sea Res. II, 50, 3143-3169, 2003.

Grimalt, J. O., Rullkötter, J., Sicre, M. A., Summons, R., Farrington, J., Harvey, H. R., Goñi, M., and Sawada, K.: Modifica- 
tions of the $\mathrm{C} 37$ alkenone and alkenoate composition in the water column and sediment: Possible implications for sea surface temperature estimates in paleoceanography, Geochem. Geophys. Geosyst., 1, paper number 2000GC000053, 2000.

Haidar, A. T. and Thierstein, H. R.: Coccolithophore dynamics off Bermuda (N. Atlantic), Deep-Sea Res. II, 48, 1925-1956, 2001.

Harvey, H. R.: Alteration processes of alkenones and related lipids in water columns and sediments, Geochem. Geophys. Geosyst., 1, paper number 2000GC000054, 2000.

Herbert, T. D., Schuffert, J. D., Thomas, D., Lange, C., Weinheimer, A., Peleo-Alampay, A., and Herguera, J. C.: Depth and seasonality of alkenone production along the California margin inferred from a coretop transect, Paleoceanography, 13, 263-271, 1998.

Hoefs, M. J. L., Versteegh, G. J. M., Rijpstra, W. I. C., de Leeuw, J. W., and Damste, J. S. S.: Postdepositional oxic degradation of alkenones: Implications for the measurements of palaeo sea surface temperatures, Paleoceanography, 17, 42-49, 1998.

Iglesias-Rodriguez, M. D., Brown C. W., Doney S. C., Kleypas J., Kolber D., Kolber Z., Hayes P. K., and Falkowski P. G.: Representing key phytoplankton functional groups in ocean carbon cycle models: Coccolithophorids, Global Biogeochem. Cycles, 16(4), 1100, doi:10.1029/2001GB001454, 2002.

IOC, IHO and BODC: Centenary Edition of the GEBCO Digital Atals, published on CD-ROM on behalf of the Intergovernmental Oceanographic Commission and the International Hydrographic Organization as part of the General Bathymetric Chart of the Oceans; British Oceanographic Data Center, Liverpool, 2003.

Kara, A. B., Rochford, P. A., and Hurlburt, H. E.: Naval Research Laboratory Mixed Layer Depth (NMLD) Climatologies, NRL Report No. NRL/FR/7330-02-9995, 26 pp., 2002.

Klaas, C. and Archer, D. E.: Association of sinking organic matter with various types of mineral ballast in the deep sea: Implications for the rain ratio, Global Biogeochem. Cycles, 16, 1116, doi:10.1029/2001GB001765, 2002.

Köbrich, M. I. and Baumann, K.-H.: Seasonal and interannual variability of coccolithophore flux and species composition off NW Africa (Cape Blanc), J. Nannoplankton Res., 26(2), 68, 2004.

Kriest, I.: Different parameterizations of the marine snow in a 1Dmodel and their influence on the representation of marine snow, nitrogen budget and sedimentation, Deep Sea Res. I, 49, 21332162, 2002.

Kriest, I. and Evans, T. E.: Representing phytoplankton aggregates in biogeochemical models, Deep Sea Res. I, 46, 1841-1859, 1999.

Large, W. G., McWilliams, J. C., and Doney, S. C.: Ocean vertical mixing: A review and a model with a nonlocal boundary layer parameterization, Rev. Geophys., 32, 369-403, 1994.

Lee, K. E. and Schneider, R.: Alkenone production in the upper $200 \mathrm{~m}$ of the Pacific Ocean, Deep Sea Res. I, 52, 443-456, 2005.

Le Quéré, C., Harrison, S. P., Prentice, I. C., Buitenhuis, E. T., Aumont, O., Bopp, L., Claustre, H., Cotrim da Cunha, L., Geider, R., Giraud, X., Klaas, C., Kohfeld, K. E., Legendre, L., Manizza, M., Platt, T., Rivkin, R. B., Sathyendranath, S., Uitz, J., Watson, A. J., and Wolf-Gladrow, D.: Ecosystem dynamics based on plankton functional types for global ocean biogeochemistry models, Global Change Biology, 11(11), 2016-2040, doi:10.1111/j.1365-2486.2005.1004.x, 2005.

Levitus, S. and Boyer, T. P.: World Ocean Atlas 1994, vol. 4: Temperature, NOAA Atlas NESDIS 4, 129 pp., 1994.
Levitus, S., Burgett, R., and Boyer, T. P.: World Ocean Atlas 1994, vol. 3: Salinity, NOAA Atlas NESDIS 3, 111 pp., 1994.

Marchesiello, P., McWilliams, J. C., and Shchepetkin, A.: Equilibrium structure and dynamics of the California current system, J. Phys. Ocean., 33, 753-783, 2003.

Marlowe, I. T.: Lipids as palaeoclimatic indicators. PhD thesis, Univ. Bristol, England, 1984.

Merico, A., Tyrrell, T., Lessard, E. J., Oguz, T., Stabeno, P. J., Zeeman, S. I., and Whitledge, T. E.: Modelling phytoplankton succession on the Bering Sea shelf: role of climate influences and trophic interactions in generating Emiliana huxleyi blooms 1997-2000, Deep Sea Res. I, 51, 1803-1826, 2004.

Mittelstaedt, E.: The ocean boundary along the northwest African coast: Circulation and oceanographic properties at the sea surface, Prog. Oceanog., 26, 307-355, 1991.

Mollenhauer, G., Eglinton, T. I., Ohkouchi, N., Schneider, R. R., Müller, P. J., Grootes, P. M., and Rullkötter, J.: Asynchronous alkenone and foraminifera records from the Benguela Upwelling System, Geochimica et Cosmochimica Acta, 67, 2157-2171, 2003.

Mollenhauer, G., Kienast, M., Lamy, F., Meggers, H., Schneider, R. R., Hayes, J. M., and Eglinton, T. I.: An evaluation of ${ }^{14} \mathrm{C}$ age relationship between co-occurring foraminifera, alkenones, and total organic carbon in continental margin sediments, Paleoceanography, 20, PA1016, doi:10.1029/2004PA001103, 2005.

Moore, J. K., Doney, S. C., Kleypas, J. A., Glover, D. M., and Fung, I. Y.: An intermediate complexity marine ecosystem model for the global domain, Deep Sea Res., 49, 403-462, 2002.

Moore, J. K., Doney, S. C., and Lindsay, K.: Upper ocean ecosystem dynamics and iron cycling in a global threedimensional model, Global Biogeochem. Cycles, 18, GB4028, doi:10.1029/2004GB002220, 2004.

Morel, A.: Process studies in eutrophic, mesotrophic and oligotrophic regimes within the tropical northeast Atlantic, in: The Changing Ocean Carbon Cycle: A Midterm Synthesis of the Joint Global Ocean Flux Study, edited by: Hanson, R. B., Ducklow, H. W., and Field, J. G., Cambridge Univ. Press, New York, 338-374, 2000.

Müller, P. J., Kirst, G., Ruhland, G., von Storch, I., and RosellMelé, A.: Calibration of the alkenone paleotemperature index $\mathrm{U}_{37}^{K^{\prime}}$ based on coretops from the eastern South Atlantic and the global ocean $\left(60^{\circ} \mathrm{N}-60^{\circ} \mathrm{S}\right)$, Geochim. Cosmochim. Acta, 62, 1757-1722, 1998.

Müller, P. J. and Fischer, G.: A 4-year sediment trap record of alkenones from the filamentous upwelling region off Cape Blanc, NW Africa and a comparison with distributions in underlying sediments, Deep Sea Res. I, 48, 1877-1903, 2001.

Müller, P. J. and Fischer, G.: Global coretop calibration of UK37 (update), PANGAEA, doi:10.1594/PANGAEA.126662, 2003.

Oschlies, A. and Garçon, V.: An eddy-permitting coupled physicalbiological model of the North Atlantic 1 . Sensitivity to advection numerics and mixed layer physics, Global Biogeochem. Cycles, 13, 135-160, 1999.

Peterson, E. L.: Benthic shear stress and sediment condition, Aquacultural Engineering, 21, 85-111, 1999.

Physical Oceanography DAAC: AVHRR Pathfinder Gobal $9 \mathrm{~km}$ Pentad SST Climatology (NOAA/NASA). NASA JPL Physical Oceanography DAAC, Pasadena, CA, 2001. 
Prahl, F. G., Muehlhausen, L. A., and Zahnle, D. L.: Further evaluation of long-chain alkenones as indicators of Paleoceanographic conditions, Geochemica Cosmochimica Acta, 52, 2303-2310, 1988.

Prahl, F. G., Wolfe, G. V., and Sparrow, M. A.: Physiological impacts on alkenone paleothermometry, Paleoceanog., 18, 1025, doi:10.1029/2002PA000803, 2003.

Prahl, F. G., Popp, B. N., Karl, D. M., and Sparrow, M. A.: Ecology and biogeochemistry of alkenone production at station ALOHA, Deep Sea Res. I, 52, 699-719, 2005.

Ribbe, J. and Holloway, P. E.: A model of suspended sediment transport by internal tides, Cont. Shelf Res., 21, 395-422, 2001.

Röske, F.: An atlas of surface fluxes based on the ECMWF reanalysis - a climatological dataset to force global ocean general circulation models, Max Planck Institut f. Meteorologie, report 323, pp. 41, 2001.

Rontani, J. F., Bonin, P., Jameson, I., and Volkman, J. K.: Degradation of the alkenones and related compounds during oxic and anoxic incubation of the marine haptophyte Emiliana huxleyi with bacterial consortia isolated from microbial mats from the Camargue, France, Org. Geochem., 36, 603-618, 2005.

Sachs, J. P. and Anderson, R. F.: Fidelity of alkenone paleotemperatures in southern Cape Basin sediment drifts, Paleoceanography, 18, 1082, doi:10.1029/2002PA000862, 2003.

Sawada, K. and Shiraiwa, Y.: Alkenone and alkenoic acid compositions of the membrane fractions of Emiliana huxleyi, Phytochem., 65, 1299-1307, 2004.

Schiebel, R., Zeltner, A., Treppke, U. F., Waniek, J. J., Bollmann, J., Rixen, T., and Hemleben, C.: Distribution of diatoms, coccolithophores and planktic foraminifers along a trophic gradient during SW monsoon in the Arabian Sea, Mar. Micropal., 51, 345-371, 2004.

Shchepetkin, A. F. and McWilliams, J. C.: A method for computing horizontal pressure-gradient force in an oceanic model with a non-aligned vertical coordinate, J. Geophys. Res.-Oceans, 108(C3), 3090, doi:10.1029/2001JC001047, 2003.
Shchepetkin, A. F. and McWilliams, J. C.: The regional oceanic modeling system (ROMS): a split-explicit, free-surface, topography-following-coordinate oceanic model, Ocean Modelling, 9, 305-404, 2005.

Sicre, M. A., Ternois, Y., Paterne, M., Boireau, A., Beaufort, L., Martinez, P., and Bertrand, P.: Biomarker stratigraphic records over the last 150 kyears off the NW African coast at $25^{\circ} \mathrm{N}$, Organic Geochem., 31, 577-588, 2000.

Sicre, M. A., Ternois, Y., Paterne, M., Martinez, P., and Bertrand, P.: Climatic changes in the upwelling region off Cap Blanc, NW Africa, over the last 70 kyear: a multi-biomarker approach, Organic Geochemistry, 32, 981-990, 2001.

Sprengel, C., Baumann, K.-H., Henderiks, J., Henrich, R., and Neuer, S.: Modern coccolithophore and carbonate sedimentation along a productivity gradient in the Canary Islands region: seasonal export production and surface accumulation rates, DeepSeas Res., 49, 3577-3598, 2002.

Thomsen, L., van Weering, T., and Gust, G.: Process in the benthic boundary layer at the Iberian continental margin and their implication for carbon mineralization, Prog. in Ocean., 52, 325-329, 2002.

Tilstone, G. H., Miguez, B. M., Figueiras, F. G., and Fermin, E. G.: Diatom dynamics in a coastal ecosystem affected by upwelling: coupling between species succession, circulation and biogeochemical processes, Mar. Ecology Prog. Series, 205, 2341, 2000.

Volkman, J. K., Barrett, S. M., Blackburn, S. I., and Sikes, E. L.: Alkenones in Gephyrocapsa oceanica: Implications for studies of paleoclimate, Geochim. Cosmochim. Acta, 59(3), 513-520, 1995.

Zhao, M., Eglinton, G., Haslett, S. K., Jordan, R. W., Sarnthein, M., and Zhang, Z.: Marine and terrestrial biomarker records for the last 35000 years at ODP site 658C off NW Africa, Organic geochemistry, 31, 919-930, 2000. 